\title{
Sylwetka innowacyjnego menedżera w oparciu o biografie edukacyjne menedżerów
}

Streszczenie: W artykule zaprezentowano fragmenty biografii edukacyjnych innowacyjnych menedżerów. Tę grupę zawodową charakteryzuje duża różnorodność doświadczeń edukacyjnych i zawodowych. Biografie edukacyjne innowacyjnych menedżerów pozwoliły odkryć najistotniejsze punkty zwrotne ich karier edukacyjnych oraz wyodrębnić te czynniki o charakterze edukacyjnym, które znacząco wpłynęły na kształtowanie kompetencji innowacyjnych. Analizie poddano zarówno wpływ edukacji formalnej, pozaformalnej, jak i nieformalnej. Badania jakościowe odnoszą się do subiektywnej rzeczywistości, pozwalają odkryć jednostkowe, unikatowe aspekty edukacji reprezentantów tej zróżnicowanej grupy zawodowej.

Słowa kluczowe: innowacyjny menedżer, edukacja w miejscu pracy, klimat organizacyjny, klimat innowacyjny, kompetencje menedżerskie, biografia edukacyjna, biografie menedżerów.

\section{The profile of the innovative manager based on educational biographies of the managers}

Summary: This article presents the studies of educational biographies of the innovative managers. This professional group has a large variety of educational and professional experiences. Educational biographies of the innovative managers have revealed the most important turning points in their educational careers and allowed to select those educational factors, which significantly influenced the course of their innovative competences. I have analyzed both the impact of formal education and non-formal as well as informal. Qualitative researches have proved subjective, however, revealed the individual, unique aspects of education and career, representative for this different professional groups.

Keywords: innovative competences of manager, education in the workplace, organizational climate, the climate for innovation, managers skills, educational biography, biographies of managers.

${ }^{*}$ Społeczna Akademia Nauk, Instytut Pedagogiki, Katedra Pedagogiki, Łódź, ul. Sienkiewicza 9; nawratd@wp.pl 


\section{Wprowadzenie}

Praca zawodowa pochłania z reguły ponad połowę życia dorosłego człowieka, jego czasu, zaangażowania, energii życiowej, uwagi. Wykonywany zawód kształtuje tożsamość społeczną jednostki, wpływa na jej status w społeczeństwie, postawy życiowe, światopogląd, jakość życia - także członków rodziny. Jest to obszar życia, który wymaga dużych inwestycji osobistych, a jednocześnie wzbudza najwięcej oczekiwań, zarówno finansowych, jak i pozamaterialnych. Kariera i rozwój zawodowy motywują do ciągłego uczenia się i podnoszenia kwalifikacji. W dobie budowania społeczeństwa wiedzy, rozwoju kapitału intelektualnego i realizacji strategii uczenia się przez całe życie środowisko pracy pełni również funkcje: edukacyjną i kulturotwórczą, gdyż praca zawodowa nierozerwalnie splata się w różnych wymiarach i zakresach z szeroko rozumianą edukacją: formalną, pozaformalną i nieformalną.

Jedną z grup zawodowych zorientowanych na permanentne uczenie się są menedżerowie. Wynika to z roli i funkcji menedżera, który musi nie tylko stale aktualizować wiedzę i umiejętności profesjonalne powiązane $\mathrm{z}$ daną branżą, ale także rozwijać i doskonalić kompetencje ponadprofesjonalne, niezbędne w pełnieniu zadań menedżerskich w turbulentnym otoczeniu rynkowym. Dynamika rozwoju cywilizacyjnego współczesnego świata, stale rosnąca konkurencyjność i wynikający z nich nacisk na przyspieszanie wzrostu gospodarczego powodują, że w zawodzie menedżera niezbędne stały się te kompetencje, które umożliwiają efektywne działanie w sytuacji zmiany, niepewności, ryzyka i różnorodności. Są to czasy dla innowacyjnych menedżerów.

Menedżerowie stanowią swoistą grupę zawodową, interesującą z punktu widzenia badań biograficznych, ze względu na olbrzymie zróżnicowanie przejawiające się między innymi: w rozmaitych profilach wykształcenia menedżerów, przebiegu ich karier edukacyjnych i zawodowych, jak również w wielorakości i dynamice pełnionych ról i zadań zawodowych. O wyjątkowości tej grupy stanowi także czynnik odniesionego sukcesu zawodowego, jak również cechy osobowe menedżerów, które predestynują do wyboru takiego typu kariery zawodowej. W niniejszej pracy prezentuję fragmenty biografii edukacyjnych menedżerów. Ukazuję te wątki biograficzne, które wpłynęły na kształtowanie się kompetencji innowacyjnych badanych.

Przedstawione badania stanowią część większego projektu badawczego o charakterze ilościowo-jakościowym, prowadzonego w 7 polskich przedsiębiorstwach. W czterech z nich realizowany był program doskonalenia kompetencji menedżerskich noszący nazwę: „Zarządzanie innowacyjne” oraz program zarządczy skierowany na podnoszenie innowacyjności w tych organizacjach. Instytucje te to: zakłady usługowe i produkcyjne, wyższa uczelnia oraz firma szkoleniowa. Pozostałe trzy firmy nieobjęte tym programem to: hurtownia farmaceutyczna, bank oraz 
spółka produkcyjna. Badaniem objęto w sumie 93 menedżerów i 381 pracowników tych przedsiębiorstw. Przedmiotem badań w obrębie całego projektu były między innymi: postawy twórcze pracowników i menedżerów, kompetencje innowacyjne menedżerów oraz klimat organizacyjny i innowacyjny. Badania prowadzone były w dwóch etapach: pierwszy stanowiły badania ilościowe, drugi zaś służył pogłębieniu badanych zjawisk - były to badania biograficzne. W II etapie uczestniczyło 15 menedżerów, którzy brali już udział we wcześniejszym (I) etapie.

W niniejszej publikacji prezentuję niewielkie fragmenty badań. Przedstawiam wybrane wątki biograficzne problemowo, odnosząc się do wyodrębnionych kategorii analitycznych, a nie opisując historii poszczególnych osób. Szczegóły metodologiczne badań ograniczyłam do niezbędnego minimum, omawiając w dwóch pierwszych rozdziałach wybrane konteksty teoretyczne, stanowiące podwaliny badań.

\section{Organizacyjne konteksty twórczości i innowacji}

Innowacyjność to niezbędna cecha współczesnych przedsiębiorstw, która jest ujmowana jako zdolność organizacji do stałego poszukiwania, wdrażania i upowszechniania innowacji. Stanowi ona wyzwanie w zarządzaniu przedsiębiorstwem. Wynika to z faktu konkurencyjności na rynku, gdzie szansę rozwoju mają te organizacje, które w sposób innowacyjny wprowadzają nowe produkty, udoskonalają procesy i są gotowe na zmiany. „Innowacyjność powinna stać się dzisiaj główną siłą kreatywną każdej organizacji, wpisaną trwale w jej system zarządzania i kulturę" (Pomykalski, 2001, s. 18). Konkurencyjność na świecie stale rośnie, zatem gospodarki państw lub wspólnot, jak również poszczególne przedsiębiorstwa muszą nieustannie uczyć się, rozwijać i udoskonalać zarówno produkty, jak i sposób działania. Przykładem jest Unia Europejska, która przeznacza ogromne środki na dofinansowanie programów wspierania innowacyjności we wszystkich sektorach gospodarki na poziomach centralnym i regionalnym, zaś rok 2009 ogłosiła międzynarodowym rokiem kreatywności i innowacji. Podnoszenie innowacyjności ma więc znaczenie zarówno w skali mikro (jednostkaprzedsiębiorstwo), jak i makro (państwo-Europa-świat), stała się ona cenioną i pożądaną wartością we współczesnym świecie.

Innowacyjność jako pojęcie wiąże się i przepląta znaczeniowo w języku potocznym z terminami: kreatywność, twórczość czy niekiedy transgresja. W zakresie nauk o organizacji i zarządzaniu częściej używa się terminów: „kreatywność”, „innowacyjność”, „innowacja”, rzadziej mówi się o „twórczości”. Terminy te, choć niekiedy bywają używane zamiennie, przez badaczy przedmiotu są różnicowane znaczeniowo (Karwowski, 2009; West, 2000). Dlatego krótko omawiam powiązania i różnice semantyczne pomiędzy nimi. 
Twórczość jest kategorią bardzo szeroką i definiowaną w wieloraki sposób, w zależności od domeny, podejścia, dyscypliny, obiektu (dzieło, proces, dorobek) lub specyficznych kryteriów wartościowania. W kontekście organizacyjnym także używa się pojęcia twórczość: np. twórcze zarzadzanie (Proctor, 2001; Nęcka, 2001; Sloane, 2005 i in.), twórczy klimat pracy czy kompetencje twórcze, jednak stosunkowo rzadko. Sformułowano kilkaset definicji samego pojęcia oraz wiele typologii cech charakteryzujących osoby twórcze, które nierzadko są ze sobą sprzeczne (Davis, 1999, za: Szmidt, 2007 i in.). Badacze zwracają uwagę na nowość jako specyficzną cechę twórczości zarówno w odniesieniu do wytworu, idei, procesu, jak też sposobu postrzegania rzeczywistości. Twórczość rozumiana jest jako specyficzna aktywność człowieka, rodzaj działania lub proces, które prowadzą do powstania oryginalnego produktu symbolicznego lub materialnego, „nowego i wartościowego dla pewnej grupy osób” (Nęcka, 2001, s. 13), uznanego za ,użyteczny, nowy, nienotowany [...] dotąd nieznany, a zarazem społecznie wartościowy" (Pietrasiński, 1969, s. 6-10), w określonym czasie, w sensie obiektywnym lub subiektywnym. Odnosi się również do specyficznych właściwości osoby-twórcy, jego: osobowości, umiejętności, zdolności (np. do wszelkiego rodzaju kompetencji), wytworów, pomysłów, które są nowe lub nowatorskie i nie były uprzednio znane osobie wytwarzającej (Popek, 2001), sposobu myślenia, wyobraźni czy też postawy twórczej (Amabile, 1983). Csikszalmychalyi (1996) wyodrębnił 10 przeciwstawnych grup cech, które posiadają osoby twórcze, łącząc je i balansując pomiędzy nimi, lub posiadają cechy skrajnie przeciwstawne. W ostatnich latach coraz większą uwagę poświęca się egalitarnemu podejściu do twórczości, czego odzwierciedleniem jest popularność koncepcji „twórczości codziennej" - everyday creativity (red. Runco, Richards, 1998, za: Schmidt, 2001a). Termin ten odnosi się zarówno do osobowości twórczej, jak i do twórczych wytworów (produktów, idei, zachowań), związanych z codzienną aktywnością człowieka w pracy i w czasie wolnym (Richards, 1999). Wytwory te moga charakteryzować się zarówno oryginalnością (zawierającą nowość i niezwykłość), jak i pewnym znaczeniem dla innych osób. Twórczość codzienna dotyczy bardziej procesu tworzenia niż jego wytworów i jest własnością niemal wszystkich ludzi, którzy poszukują zadań rozwojowych i sensu życia. Związana jest z motywacją do wzrostu i rozwoju oraz zdolnością człowieka do pokonywania trudności. Mimo, że pozostaje często niezauważona i niedoceniona (nienagrodzona), pomaga osiągnąć dobrostan psychiczny i służy zdrowiu psychicznemu, dzięki niej umacniają się siły fizyczne i psychiczne, a twórca może stawić czoło przeciwnościom losu i rozwijać stałą tendencję do samorealizacji (Schmidt, 2001). Ta koncepcja pokazuje, że twórczość towarzyszy ludziom na co dzień, w życiu codziennym i zawodowym. Małe, ale odkrywcze pomysły, drobne udoskonalenie czegoś czy nowe spojrzenie na „stary” problem może być źródłem innowacji - także w procesie pracy. 
W odniesieniu do organizacji najczęściej używany jest termin innowacja, odnoszący się do zmiany organizacyjnej lub rozwoju organizacji (Penc, 1999, s. 141), adaptowania nowych lub sprawdzonych rozwiązań, postępu, wynalazczości (np.: nowości techniczne, nowe technologie lub pierwsze praktyczne wykorzystanie wynalazku), wdrażania nowych produktów oraz ich udoskonalania lub modyfikowania. Innowacją może być pomysł istniejący od dawna, ale stanowiący innowację dla osoby (grupy osób), która go postrzega jako nowy, lub znalezienie i „urynkowienie” już istniejącego pomysłu. „Innowacja to każda świadoma, funkcjonalna, pozytywna i postępowa zmiana materialnych i niematerialnych elementów (parametrów) jednostki organizacyjnej, tj. każda zmiana sprzyjająca jej rozwojowi, wzrostowi oraz zwiększeniu efektywności” (Perlaki, za: J. Penc, 1999, s. 142). Łacińskie słowo innovatio oznacza „odnawianie”, zaś innowacja to „wprowadzenie czegoś nowego, rzecz nowo wprowadzona, nowość nowatorstwo, reforma" (Słownik Języka Polskiego, 1978, s. 254). Cechą innowacji, podobnie jak twórczości, jest jej „,nowość”, jednak zasadniczą różnicą pomiędzy tymi pojęciami jest celowość. W przypadku innowacji jej głównym celem jest zmiana na „lepsze”, udoskonalenie, modernizacja, wzrost efektywności czy rentowności prowadzące do wdrożenia zmian, udoskonalenia, modernizacji. Innowacja zawsze ma wymiar praktyczny, jest celowa i musi przynieść konkretne, mierzalne korzyści. Realizowana jest w sposób systematyczny poprzez precyzyjnie zaplanowane działania (zawiera harmonogram zadań, kosztorys, szacunek ryzyk itp.) oraz sprecyzowane, mierzalne w określony sposób rezultaty. W kontekstach organizacyjnych kompetencje pracownika mają zawsze odniesienie do strategii przedsiębiorstwa, zatem bardziej zasadne jest stosowanie określenia ,innowacyjny" w stosunku do działalności człowieka na rzecz organizacji. Twórczość jako postawa człowieka i jego potencjał osobowy może stanowić natomiast źródło innowacji. Innowacyjność to kompetencja człowieka do wdrażania twórczych pomysłów w określonej rzeczywistości.

Innym popularnym, wydaje się wręcz, że uniwersalnym w potocznym rozumieniu pojęciem, stosowanym powszechnie w kontekstach organizacyjnych jest kreatywność. Słowo powstało na skutek spolszczenia angielskiego słowa creativity (kreatywność, twórczość) ${ }^{1}$. Rozumiane jest ono głównie jako cecha indywidualna osoby, potencjał osobowy, kojarzony z takimi cechami, jak dynamiczność, aktywność, sumienność (Karwowski, 2009, s. 38) oraz przedsiębiorczość i pomysłowość. Potocznie termin ,kreatywny” w odniesieniu do określenia potencjału osobowego człowieka synonimicznie zastępowany bywa terminem „twórczy” (badania Karwowskiego, 2009), co jest dość mylące, gdyż zakres znaczeniowy pojęcia „kreatywność” jest znacznie węższy i mniej pojemny.

${ }^{1}$ Słowa bliskoznaczne do ang. creativeness - kreatywność, pomysłowość, zdolność (ability to...) do tworzenia, kreowania; create - tworzyć, ustanawiać, wprowadzać w życie (źródło: www. ling.pl [dostęp 30.06.2012]). 
Kategorią powiązaną z omawianymi wcześniej, pojawiającą się w kontekstach organizacyjnych jest transgresja. Organizacje transgresyjne to organizacje twórcze, czyli takie, które muszą być zdolne do przekraczania własnych granic. Wyróżniają je następujące cechy i wartości kulturowe: proaktywność, podmiotowość, równość, wspólnotowość, transfer wiedzy oraz wysoka tolerancja niepewności (Sułkowski, 2002, Mesjasz, 2006). Twórcze aspekty przejawiają się w tym, że organizacja taka inicjuje i realizuje samoistnie działania innowacyjne i ekspansywne, które powodują, że organizacja rozwija się, przekraczając swoje dotychczasowe granice i obszary funkcjonowania, dzięki czemu tworzy nowe wartości oraz realizuje nowe interesy. Organizacja transgresyjna nastawiona jest na uczenie się i rozwój. Niektóre właściwości organizacji transgresyjnej korespondują z cechami organizacji uczącej się zdefiniowanymi przez A. Sajkiewicz (2002, s. 69) jako:

- postrzeganie procesów jako problemów wymagających ciągłego rozwiązywania,

- podejmowanie ryzykownych i odpowiedzialnych zadań,

- umiejętność uczenia się na podstawie doświadczenia,

- przyswajanie zewnętrznych wzorców rozwiązań i ich adaptacja do lokalnych warunków,

- wewnętrzna popularyzacja wiedzy o planowanych przedsięwzięciach w otwartym systemie informacyjnym.

Nie ulega wątpliwości, że bez względu na przyjęte kategorie pojęciowe nowoczesne, uczące się organizacje potrzebują twórczych, kreatywnych i innowacyjnych pracowników oraz efektywnie zarządzających tymi kompetencjami menedżerów.

\section{Innowacyjne kompetencje menedżerskie}

Sylwetka, osobowość, kompetencje współczesnego menedżera są problematyką bardzo szeroką, badaną z perspektywy nauk o zarządzaniu, psychologii, socjologii, filozofii i pedagogiki. W nowych typach organizacji, o którym była wcześniej mowa, nie wystarczy, że menedżer sam jest innowacyjny. Jego zadaniem jest kierować nie tylko procesami innowacyjnymi, ale także potencjałem pracowników w tym zakresie. Oznacza to umiejętności w zakresie szacowania potencjału twórczego i innowacyjnego, stymulowania pracowników do pożądanych zachowań, motywowania w trudnym procesie wdrażania innowacji lub zmian oraz wspierania $\mathrm{w}$ trudnościach i pomoc $\mathrm{w}$ twórczym rozwiązywaniu problemów. Wdrażanie innowacji jest z natury swej związane z pewnym ryzykiem, niepewnością, mierzeniem się z nieprzewidywalnymi zdarzeniami, które mogą wystąpić lub nie. Przed współczesnym menedżerem stawiane są więc wysokie wymagania. W rozdziale tym prezentuję, jak definiowane są kompetencje zawodowe, w tym menedżerskie, przez badaczy zjawisk. 


\subsection{Różne ujęcia kompetencji zawodowych}

Kompetencje są pojęciem bardzo szerokim i w ostatnim czasie poddawanym głębokiej analizie i dyskusji. Kompetencje człowieka najczęściej rozumiane są jako umiejętność, zdolność lub gotowość do wykonywania określonych czynności. Przez Radę Europy określane zostały jako: ,połączenie wiedzy, umiejętności i postaw odpowiednich do sytuacji” Dziennik Urzędowy UE...), a kompetencje kluczowe to te, „których wszystkie osoby potrzebują do samorealizacji i rozwoju osobistego, bycia aktywnym obywatelem, integracji społecznej i zatrudnienia" (ibidem). W Polskiej Ramie Kwalifikacji kompetencje zdefiniowano jako: „wszystko to, co dana osoba wie, rozumie i potrafi wykonać, czyli jej skumulowane efekty uczenia się" (IBE, 2012)

Realizacja postulatów strategii uczenia się przez całe życie oznacza ciągłe doskonalenie kompetencji zawodowych i podnoszenia kwalifikacji. Polityka ta jest silnie promowana przez Unię Europejską zarówno w kontekście budowania kapitału intelektualnego i wzmacniania konkurencyjności państw Europy, jak również w obliczu obecnych i przyszłych zmian w stanie i strukturze rynku pracy, które nie są optymistyczne. Kompetencje zawodowe stały się więc przedmiotem uwagi, są diagnozowane, opisywane, klasyfikowane, a przedsiębiorstwa starają się jak najefektywniej zarządzać nimi. Są one z reguły definiowane kompleksowo, jako całokształt wiedzy, umiejętności, uzdolnień, stylów działania, osobowości, postaw, wyznawanych zasad i wartości, zainteresowań oraz tych cech, które - używane i rozwijane w procesie pracy - prowadzą do osiągnięcia rezultatów zgodnych ze strategicznymi zamierzeniami przedsiębiorstwa (Rostowski, Sienkiewicz, 2003). Autorzy ci, jak wielu innych badaczy organizacji, podkreślają, że posiadane przez pracowników kompetencje powinny stanowić nie tylko wymierną korzyść dla organizacji z punktu widzenia jej zamierzeń strategicznych, ale przede wszystkim mają być motorem rozwoju zarówno organizacyjnego, jak i jednostkowego. Inni zwracają uwagą na ich potencjalność: kompetencje to „dyspozycje w zakresie wiedzy, umiejętności i postaw pozwalające realizować zadania zawodowe na odpowiednim poziomie" (Filipowicz, 2004, s. 17). Jak również stwierdzają, że jest to „zdolność pracownika do działania prowadzącego do osiągnięcia zamierzonego celu $\mathrm{w}$ danych warunkach za pomocą określonych środków [...] ogół wiedzy, umiejętności, doświadczeń, postaw i gotowość pracownika do działania w danych warunkach, a więc także zdolność przystosowania się do tych zmieniających się warunków" (Thierry, Sauret, 1994, s. 6, za: Król, 2006, s. 81). Kompetencje zawodowe stanowią z jednej strony indywidualny zasób osoby - pracownika - aktywnego uczestnika rynku pracy, z drugiej zaś traktowane są jako zasoby intelektualne organizacji, gdyż na jej gruncie zyskują one lub tracą swoją wartość - realizują się zatem i rozwijają w konkretnych uwarunkowaniach organizacyjnych. 


\subsection{Kompetencje menedżerskie}

Istnieje wiele klasyfikacji kompetencji zawodowych, a w każdej z nich wyróżnia się kompetencje menedżerskie. Stanowią one bowiem jeden z istotniejszych zasobów każdego przedsiębiorstwa, są jego wyróżnikiem na rynku, najcenniejszą wartością niematerialną firmy oraz czynnikiem tworzącym trwałą przewagę konkurencyjną. W literaturze przedmiotu znajdujemy wiele typologii kompetencji menedżerskich. Jedną z najbardziej „,klasycznych” jest koncepcja Katza i Kahna (1979), którzy podzielili kompetencje na trzy podgrupy: koncepcyjne, techniczne i interpersonalne (społeczne). Badacze ci uważają sprawności konceptualne za kluczowe na stanowisku menedżerskim, ponieważ pomagają one w postrzeganiu organizacji jako całości, w widzeniu zależności pomiędzy poszczególnymi działaniami oraz między zmiennym otoczeniem a organizacją. Ponadto im wyższy szczebel zarządzania, tym są one cenniejsze; niezbędne są bowiem w kreowaniu wizji, planowaniu strategii i innowacji. Im niższy szczebel zarządzania, tym istotniejsze są kompetencje techniczne (w tym zawodowe - branżowe, organizacyjne, administracyjne). Kompetencje interpersonalne są uważane za „uniwersalne”, ważne na każdym poziomie kierowania ludźmi, a znaczenie ich stale rośnie. Zalicza się do nich między innymi: umiejętność komunikowania się, delegowania zadań, motywowania, rozwiązywania konfliktów, pracy zespołowej i budowania zespołu oraz umiejętność zdobywania władzy i wpływu (Rakowska, Sitko-Lutek, 2000).

Współcześni badacze wskazują także na wiele innych subkompetencji, np. diagnostyczne ${ }^{2}$, trenerskie ${ }^{3}$, osobiste (intrapersonalne). Ranga tej ostatniej grupy kompetencji znacznie wzrosła w ostatnich latach, gdy zauważono, że w nich właśnie tkwią te właściwości, które decydują o możliwościach nabywania pozostałych. Do kompetencji osobistych zalicza się gotowość do uczenia się, wysoką motywację wewnętrzną, samoświadomość (rozumianą jako umiejętność zwiększania efektywności własnej osoby, kreowanie siebie i swojego rozwoju, zarządzanie sobą), radzenie sobie ze stresem i psychologicznymi kosztami pracy, zarządzanie czasem, umiejętność ustalania priorytetów i wartościowania, kulturę osobistą i etyczną (Rakowska, 2000; Sitko-Lutek, 2004; Mesjasz, 2006 i in.). Obecnie nikogo już nie dziwi, że ta grupa kompetencji jest przedmiotem szczególnej uwagi we wszystkich procesach personalnych w przedsiębiorstwie. Badacze Whetten i Cameron (za: Potocki, 2005, s. 236) opracowali koncepcję dziewięciu kluczo-

${ }^{2}$ Kompetencje szczególne przydatne w diagnozowaniu potencjału ludzkiego, pomocne na każdym etapie i szczeblu zarządzania, zarówno na etapie rekrutacji, jak i kierowania zespołem, oceniania, motywowania, istotne w zarządzaniu konfliktem, zarządzaniu zmianą, kreatywnością i innowacją (Penc, 1998).

${ }^{3}$ Według M. Morawskiego (2004, s. 118) kompetencje trenerskie są niezbędne w rozwoju uczących się organizacji - pomocne są w budowaniu zaufania i tworzeniu nieformalnych, sieciowych wspólnot. 
wych kompetencji menedżerskich, koncentrując się przede wszystkim na dwóch grupach umiejętności: osobistych (twórcze rozwiązywanie problemów, kierowanie stresem, doskonalenie samoświadomości) i interpersonalnych (ustanowienie wspierającej komunikacji, zdobywanie wiedzy i wpływu, kierowanie konfliktami, skuteczne delegowanie, motywowanie innych, grupowe podejmowanie decyzji). Kompetencje związane ze społecznymi wymiarami pracy menedżera, jego podejściem do świata, do ludzi i problemów można określić mianem kompetencji humanistycznych ${ }^{4}$. Zwiększają one efektywność realizacji zadań menedżerskich, sprzyjają rozwojowi i uczeniu się pracowników oraz organizacji, jednocześnie „humanizując” środowisko pracy.

Kompetencje menedżerskie doczekały się niezliczonych typologii i klasyfikacji w oparciu o liczne badania prowadzone w ostatnich latach. Niektóre przedsiębiorstwa prowadzą własne analizy w tym zakresie, opracowując listy kluczowych kompetencji, na czele których usytuowane są te, kierowane w stronę menedżerów.

\subsection{Kompetencje innowacyjnego menedżera}

Kompetencje twórcze i innowacyjne menedżerów zaliczane są często do tzw. kompetencji „miękkich” (Nęcka, 1991; Szmidt, 1998; Penc, 1999; Szopiński, 2004 i in.). Jak wspomniane było wcześniej, rośnie ,zapotrzebowanie” na te właśnie kompetencje. Badania w tym zakresie podejmowane były od wielu lat, szczególnie w Stanach Zjednoczonych, gdzie innowacyjność była i jest jedną z istotniejszych cech menedżerów i organizacji. Termin „kompetencja innowacyjna" pojawił się na gruncie psychologii i nauk o zarządzaniu. Zofia Ratajczak (1980) określiła kompetencję innowacyjną człowieka jako taką, która umożliwia mu „twórcze operowanie własnymi nawykami i cechami własnej osobowości” (Ratajczak, 1980, s. 11). Autorka upatrywała przejawów tej kompetencji w trzech wymiarach funkcjonowania człowieka w organizacji: człowiek w sytuacji innowacyjnej to ten, kto tworzy nowe rzeczy lub uczestniczy w ich wytwarzaniu, ten kto uczy się nowych rzeczy oraz ten, kto aktywnie oddziałuje na innych na rzecz przyswojenia przez nich nowości, wytrwale pokonując trudności i rozwiązując zaistniałe problemy (Ratajczak, 1980, s. 10-12). Z. Pietrasiński (1971) natomiast przyjął, że istotą kompetencji innowacyjnej jest „stosunkowo najbardziej bezpośrednie przygotowanie do wprowadzania innowacji oparte na przyswojeniu doświadczeń praktycznych i odpowiedniej wiedzy naukowej. Treść przygotowania obejmuje zarówno fazę kreatywną, jak i fazę organizacyjno-wdrożeniową" (Pietrasiński, 1971, s. 62). Badacz ten zwrócił uwagę na znaczącą rolę rzetelnego przygotowania projektu innowacyjnego, stworzenie odpowiednich warunków do

${ }^{4}$ Model humanistycznych kompetencji menedżerskich opracowany przez D. Nawrat (2009) zawiera 3 grupy subkompetencji: intrapersonalne, interpersonalne i twórcze. 
wdrożenia innowacji oraz istotne znaczenie wiedzy, jaką o procesie innowacji powinien mieć menedżer. Takie rozumienie kompetencji innowacyjnej aktualne jest także i dziś.

Jak podkreślałam wcześniej, w przyjętym przeze mnie założeniu kompetencje innowacyjne powiązane są z postawą twórczą. Dlatego odnoszę się do tego zagadnienia, ponadto $\mathrm{w}$ badaniach własnych wykorzystałam kwestionariusz do badania postaw twórczych KAHN autorstwa S. Popka (2001), chcąc oszacować potencjał twórczy (poprzez badanie nasilenia postawy twórczej) badanych pracowników i menedżerów. Jedną z najbardziej rozpowszechnionych w Polsce definicji postawy twórczej jest ta sformułowana przez S. Popka $(2000,2001)$, rozumiana jako: ,ukształtowana (genetycznie i poprzez indywidualne doświadczenie) właściwość poznawcza i charakterologiczna, wykazująca tendencję, nastawienie lub gotowość do przekształcania świata rzeczy, zjawisk, a także własnej osobowości. Jest to więc aktywny stosunek człowieka do świata i życia, wyrażający się w potrzebie poznawania, przeżywania i świadomego (co do celu, a nie procesu) przetwarzania zastanej rzeczywistości i własnego «ja»" (Popek, 1988, s. 27). W praktyce organizacyjnej kompetencje twórcze oznaczają umiejętność ciągłego uczenia się nowych wartości i wzorców działania oraz nowych sposobów pozyskiwania i transferu wiedzy (Morawski, 2004, s. 118). Badacze E. Steiner i R. Weber (1993) przypisują dominującą rolę twórczym umiejętnościom menedżerów, zaliczając do nich:

- umiejętność generowania dużej liczby pomysłów w krótkim czasie,

- ciągłe poszukiwanie nowych rozwiązań,

- oryginalność tworzenia nowatorskich powiązań i pomysłów,

- umiejętność wybrania optymalnego rozwiązania,

- wytrwałość w pokonywaniu trudności,

- motywacja jako problem i wyzwanie,

- energiczność i operatywność,

- konsekwencja, systematyczność, odwaga,

- tolerancja i poszanowanie odmiennych poglądów,

- unikanie przedwczesnego zajmowania stanowiska w sprawie,

- otwartość na krytykę,

- relatywistyczne spojrzenie na rzeczywistość,

- niezależność sądów.

Jednym z badaczy, uznających twórczość za źródło innowacji, jest Józef Kozielecki, który postrzega „człowieka innowacyjnego” jako osobowość wielowymiarową, człowieka-sprawcę, przeciwstawiając mu człowieka-odbiorcę (Kozielecki, 1987, s. 5). „Człowiek innowacyjny spostrzega otocznie nie jako trwałą i harmonijną strukturę, do której można się przystosować, ale jako zbiór pytań, na które trzeba odpowiedzieć, jako obszary niepewności poznawczej i praktycznej, które trzeba zredukować, i jako wielorakie trudności, które trzeba racjonalnie pokonać" (Kozielecki, 1987, s. 8). Jednocześnie autor ten zwraca uwagę na moż- 
liwości kształtowania kompetencji innowacyjnych człowieka: „fundamentalne znaczenie ma fakt, że człowiek, który przeszedł trening nauczania innowacyjnego ma znacznie mniejsze trudności w przystosowaniu się do przyszłego świata i kreowaniu go niż człowiek oświecony. Ten pierwszy nie przeżywa szoków przyszłości na każdym zakręcie historii. Rzadziej doznaje zaburzeń emocjonalnych. Rzadziej przeżywa depresje i akty rozpaczy. Przyszłość staje się dla niego szansą, a nie «ścianą płaczu». Słowem, wydaje się lepiej przygotowany do zmiennych kolei ludzkiego losu" (Kozielecki, 1987, s. 11). Tezę tę potwierdzają współczesne badania (Mesjasz, Nawrat, 2006), które dowiodły, że twórczy menedżerowie lepiej „,bilansują” psychologiczne koszty pracy. Ponadto przeprowadzone przeze mnie badania postrzegania klimatu organizacyjnego i innowacyjnego w przedsiębiorstwach pokazały, że badani o wysokim nasileniu postawy twórczej postrzegali klimat $^{5}$ jako bardziej innowacyjny, bardziej satysfakcjonujący i dostrzegali możliwości rozwoju także tam, gdzie osoby o niższym nasileniu postawy twórczej ich nie dostrzegały. Można więc przyjąć, że postawa twórcza predestynuje do zachowań innowacyjnych, takich jak samoistne poszukiwanie i dostrzeganie możliwości do rozwoju nawet tam, gdzie inni ich nie widzą. Wyniki badań pokazały także pewną zależność: badani z wykształceniem humanistycznym wykazywali wyższe nasilenie postawy twórczej. Nasuwa się więc pytanie: czy kształcenie humanistyczne kształtuje postawy twórcze, czy też osoby twórcze wybierają ten rodzaj kształcenia? Wyniki te dotyczyły zarówno pracowników, jak i menedżerów, choć ci ostatni wykazali ogólnie wysokie nasilenie postawy twórczej. Szczególnie jednak wysokie było wśród menedżerów z wykształceniem humanistycznym, gdzie $100 \%$ badanych posiadało wysokie nasilenie postawy twórczej.

Warto zwrócić uwagę na jeszcze jeden aspekt znaczenia tej grupy kompetencji. Menedżerowie o wysokim nasileniu postawy twórczej są bardziej wrażliwi na przejawy takiej postawy u swoich pracowników, bo, mówiąc najprościej, po prostu potrafią je dostrzec. Ponadto doceniają i kreują innowacyjny klimat pracy, poszukują wartości dodanych w twórczych pomysłach i zachowaniach pracowników (źródło: badania własne). Menedżerowie o niskim nasileniu twórczości mogą nieintencjonalnie hamować twórczy potencjał pracowników - mogą go w ogóle nie zauważyć lub niewłaściwie ocenić, a w konsekwencji, nie będą mogli go właściwie spożytkować. Zasoby ludzkie, w przeciwieństwie do zasobów naturalnych, które wyczerpują się w miarę ich wydobywania, podlegają zmianom jakościowym: potencjał kreatywny pracowników może być rozwijany lub - jeśli jest niewykorzystywany - ulega atrofii (Dobrołowicz, 2007). Badania pokazują (Mesjasz, Nawrat, 2006), że potencjał twórczy pracowników jest przez nich wykorzystywany w tych organizacjach, które stwarzają warunki sprzyjające rozwo-

${ }^{5}$ Klimat organizacyjny badany był Kwestionariuszem do Badania Klimatu Organizacyjnego L. Rosenstiela, zaś klimat innowacyjny Kwestionariuszem do Badania Klimatu Innowacyjnego S. G. Scotte'a, R. A. Bruce'a (1994), tłumaczonym i adaptowanym przez A. Paszkowską-Rogacz (1999), za zgodą. 
jowi i innowacjom (klimat innowacyjny). Organizacje, które nie stwarzają takich warunków, muszą liczyć się z tym, że pracownicy blokują swoje twórcze zasoby, co wpływa hamująco na ich rozwój, powodując wzrost ponoszonych przez nich psychologicznych kosztów pracy (Mesjasz, 2006). Szczególnie dotyczy to osób najbardziej twórczych, które albo odchodzą z takich organizacji albo deprecjonują własny potencjał, co staje się źródłem frustracji, demotywacji i w konsekwencji wypalenia zawodowego. Termin „potencjał” (z łac. potentia - możliwość, siła) oznacza dynamiczny zasób możliwości, mocy, zdolności, sprawności, co wskazuje, że jest to rodzaj energii, którą można i należy wydobywać, rozwijać i wzmacniać (Dobrołowicz, 2007). Organizacje, by sprostać wymaganiom współczesności, muszą więc postawić na te kompetencje menedżerskie, które zapewnią przedsiębiorstwu rozwój w obecnych i nieprzewidywalnych, przyszłych okolicznościach rynkowych.

\section{Innowacyjny menedżer w świetle badań biograficznych}

Do podjęcia omawianej tu problematyki badawczej skłoniły mnie, obok zainteresowań badawczych, także własne doświadczenia zawodowe. Prowadziłam szkolenia i treningi z zakresu innowacyjności dla menedżerów (także w programie „Zarządzanie innowacyjne”), jak również zajmowałam się współtworzeniem strategii personalnych skierowanych na podnoszenie innowacyjności menedżerów dla 40 firm. Dlatego też jednym z celów podjęcia badań był cel utylitarny: rezultaty badań mogą zostać zaimplementowane do praktyki edukacyjnej lub/i zarządczej.

Złożoność problematyki badawczej skłoniła mnie do poszukiwania metody umożliwiającej pogłębioną penetrację badanych zjawisk, stąd wybór metody biograficznej. Dodatkowym argumentem przemawiającym za użyciem tej metody jest przyjęcie założenia, że menedżerowie są grupą osób o wysokim stopniu samoświadomości i posiadającą wysoką zdolność do artykulacji badanych problemów, co jest jednym z warunków stosowania tej metody (Pilch, Bauman, 2001, s. 279). Badania biograficzne pozwoliły mi poznać - poprzez osobiste narracje menedżerów - ich indywidualne rozumienia doświadczeń edukacyjnych oraz tych czynników, które wpłynęły na kształtowanie kompetencji innowacyjnych oraz osiągnięcie sukcesu zawodowego.

\subsection{Biografia edukacyjna dorosłego}

Przedmiotem zainteresowania w badaniach biograficznych jest przebieg życia danej jednostki ukazujący pewien obszar aktywności, np. życie zawodowe, przebieg edukacji. Bada się również te momenty, które są związane z ważnymi wy- 
darzeniami życiowymi, zmianą ról czy pozycji społecznych. Biografie mogą być więc tematem samym w sobie lub środkiem do rozwiązania innych problemów i pytań badawczych. Przedmiot zainteresowania w badaniach biograficznych stanowi indywidualna i symboliczna interpretacja rzeczywistości. Wyrażane treści są relatywne: to opowiadający przypisuje swoim wspomnieniom znaczenia, których wcześniej nie miały, sam je interpretuje. Opis życia nie ogranicza się jedynie do przedstawienia obiektywnych faktów, ale na ich postrzeganie wpływ ma wiele czynników i kontekstów, np. społeczny i kulturowy (Giza, 1991, s. 108). Badania biograficzne pozwalają na analizę zagadnień dotyczącą zarówno poszczególnych osób, jak i zarazem zjawisk treściowo i znaczeniowo złożonych. Nie istnieje bowiem żaden obiektywny, przedmiotowy wymiar rzeczywistości społecznej; pewne jej obszary możemy poznać jedynie poprzez ukazanie ich osobistego wymiaru (Pilch, Bauman, 2001). Subiektywna perspektywa uwzględniająca własny punkt widzenia badanych staje się niezbędna w konstruowaniu uogólnień teoretycznych (Włodarek, Ziółkowski, 1990).

Szerokie podejście do pojęcia ,edukacja” przyjęłam za perspektywą andragogiczną, która pozwala wyodrębnić, na tle ogólnej biografii jednostki, biografię edukacyjną człowieka dorosłego zarówno na płaszczyźnie edukacji formalnej, nieformalnej, jak i pozaformalnej (Dubas, 2005, Kargul, 2001), związanej z uczestniczeniem $\mathrm{w}$ danym środowisku, społeczności, organizacji (Malewski, 2002). Edukację rozumiem więc jako proces uczenia się realizowany pod wpływem zewnętrznego w stosunku do jednostki oddziaływania, tj. ukierunkowanego kształcenia i wychowania - realizowanego w systemie oświaty - oraz poprzez uczestnictwo w kształceniu nieformalnym, jak również jako wynik podejmowania samokształcenia, samowychowania i uczenia się we wszystkich wymiarach aktywności człowieka i w ciągu całego jego życia. Schulze wymienia następujące typy uczenia się, biorąc pod uwagę całokształt życia człowieka:

1) samodzielne organizowanie - uczenie się z doświadczenia;

2) dyskontynuowane - uczenie się przy okazji;

3) ekologiczne - uczenie się w środowisku życia;

4) irytacyjne - uczenie się w sprzecznościach i przełomach;

5) symbolizowane - uczenie się na scenach, przypowieściach, sentencjach;

6) afektywne - uczenie się z przeżyć;

7) reflektowane (rozważane) - uczenie się w opisie (Schulze, 1985, za: Nittel, 1991, s. 102).

Szerokie ujęcie edukacji dorosłych obejmuje także uwarunkowania zarówno wewnętrzne, jak i zewnętrzne procesu uczenia się - środowisko edukacyjne. Szerokie ujęcie środowiska edukacyjnego dorosłego oznacza otoczenie zewnętrzne w stosunku do człowieka oraz jego wewnętrzną strukturę (cechy i wszystkie aspekty człowieka jako osoby) (Janowski, Przyszczypkowski, Skrzypczak, 2007, s. 20). Obydwa te czynniki współdziałają ze sobą i wpływają na aktywność podejmowaną przez jednostkę. Środowisko zewnętrzne, według tych badaczy, to śro- 
dowisko bezpośrednie, w którym funkcjonuje w sposób „fizyczny”, jak również środowisko pośrednie (np. media, sztuka, kultura, technika, nauka itp.). Według wspomnianych autorów środowisko to tworzy przestrzeń życiową człowieka, która zmienia się wraz z pełnieniem przez niego różnorodnych ról społecznych, zawodowych, obywatelskich. Pełnienie różnorodnych ról natomiast powoduje wchodzenie w różne sytuacje i środowiska, z których jedne są sprzyjające dla rozwoju, a inne nie. Człowiek dorosły, który ponosi odpowiedzialność za samego siebie, toczy nieustanną, ,grę" zarówno z otoczeniem, jak z samym sobą. W toku tej gry kształtuje się jego środowisko edukacyjne. Tak rozumiane środowisko edukacyjne dorosłego człowieka implikuje możliwość i potrzebę uwzględnienia i podkreślenia doniosłości różnorodnych środowisk edukacyjnych, jakie stanowią środowisko rodzinne, lokalne, zawodowe, edukacyjne instytucji oświatowych i pozaoświatowych, także wojsko, więzienie itp. (Janowski, Przyszczypkowski, Skrzypczak, 2007, s. 19-23).

Zagadnienia związane z edukacyjnymi aspektami biografii człowieka dorosłego ściśle łączą się z kontekstami zawodowymi. Biografia zawodowa stanowi - w świetle pedagogiki pracy - odrębną kategorię pojęciową umożliwiającą badanie procesów i zjawisk związanych z pracą człowieka. Biografia życia człowieka traktowana jest jako historia życia osoby w określonych warunkach społecznych, musi uwzględniać zatem zarówno aspekt subiektywno-przeżyciowy, jak i obiektywno-historyczny (Piorunek, 2006). Stanowi sekwencyjną i komplementarną całość, w której przeszłość - teraźniejszość - przyszłość są współpowiązane ze sobą. Przeszłość odzwierciedla się w teraźniejszości i podejmowanych aktualnie decyzjach oraz projektowaniu przyszłości. Rozwój człowieka w ciągu życia jest wypadkową interakcji między zdarzeniami życiowymi związanymi z wiekiem (poszczególnych faz życia) a sytuacją społeczno-historyczną. Bieg życia, biografia zawodowa, zadania życiowe i doświadczenia biograficzne przeplatają się z drogą edukacyjną i kształtują całościową ludzką biografię. Sfera zawodowa, obok relacji rodzinnych, definiuje także interakcje człowieka ze światem zewnętrznym (Piorunek, 2006).

Z biografią zawodową związany jest także aspekt kariery i rozwoju zawodowego. Kariera zawodowa może być rozumiana jako biografia zawodowa, jako wspinanie się poprzez szereg pozycji zawodowych ułożonych w hierarchii pionowej, z których każda znajduje się wyżej od poprzednich w odczuciu społecznym, opartym na miarach prestiżu społecznego, bogactwa, sławy lub jako sekwencja ról i pozycji zawodowych obejmowanych przez jednostkę w różnych fazach cyklu życia. Rozwój zawodowy również można rozpatrywać jako biografię zawodową jednostki. Według T. Nowackiego stanowi on drogę rozwoju zawodowego jednostki od fazy zaznajamiania z obszarami ludzkiej działalności gospodarczej i kulturalnej, poprzez fazę przygotowania ogólnozawodowego, do okresu przygotowania zawodowego, po którym następują okresy rozwoju zawodowego, awansów i osiągnięć, aż do zakończenia pracy zawodowej (Nowacki, 2004). Faza ta 
nie kończy jednak aktywności pracowniczej. Fazy rozwoju zawodowego zależą w znacznym stopniu od instytucji społecznych określających aktywność jednostki i od jej udziału w procesach kształcenia i procesach pracy. Jest to proces rośnięcia i uczenia się, któremu podporządkowane są wszelkie przejawy zachowania zawodowego, stopniowy wzrost i zmiany zdolności jednostki do określonych rodzajów zachowania zawodowego oraz powiększanie jej repertuaru zachowań zawodowych (Podolska-Filipowicz, 1996). Rozwój zawodowy obejmuje wszystkie aspekty rozwojowe, które mogą być odniesione do pracy. Jest procesem doskonalenia siebie w wymiarze ogólnym i zawodowym, postrzeganym jako nabywanie coraz to nowych dyspozycji zawodowych, umożliwiających rozwiązywanie coraz bardziej złożonych problemów w trakcie wykonywania pracy zawodowej (Wołk, 2005).

O rozwoju zawodowym człowieka decydują dwie grupy czynników (uwarunkowań):

- wewnętrzne (podmiotowe) - związane z człowiekiem, jego indywidualnymi cechami (np. uwarunkowania biologiczne, fizyczne, psychiczne);

- zewnętrzne (przedmiotowe) - znajdujące się poza człowiekiem, sytuacyjne np. uwarunkowania historyczne, ekonomiczne, techniczne, kulturowe, społeczne, polityczne i pedagogiczne (Czarnecki, Karaś, 1996).

Biografie edukacyjne menedżerów splatają się z ich biografiami zawodowymi - przebiegiem kariery zawodowej i rozwojem zawodowym.

\subsection{Aspekty metodologiczne badań}

\section{Problemy badawcze}

Formułując problemy badawcze, pytania i dyspozycje do wywiadów, przyjęłam opisane wcześniej, szerokie rozumienie edukacji i czynników edukacyjnych. Uwzględniłam więc typy edukacji: formalną, nieformalną i pozaformalną. Czynniki o charakterze edukacyjnym ujęłam jako doświadczenia związane z edukacją szkolną, pozaszkolną i posiadanym wykształceniem, ale także te związane z uczeniem się poprzez funkcjonowanie w określonym środowisku społecznym, zawodowym, jak również z uwarunkowaniami osobistymi badanych. Zgodnie jednak z przyjętą metodologią badań biograficznych, rozumienie takich pojęć, jak: „edukacja”, „czynniki edukacyjne”, „doświadczenia edukacyjne” i „kompetencje innowacyjne" pozostawiłam jako kategorię otwartą - do indywidualnej interpretacji badanych. Sformułowałam otwarte pytania badawcze, nie przyjmując hipotez, nie czyniąc założeń odnośnie do spodziewanych wyników. Wyodrębniłam natomiast kategorie, które posłużyły mi do pogrupowania problemów badawczych, a następnie do interpretacji zebranego materiału biograficznego. Poniżej przedstawiam kategorie oraz problemy ujęte w formie otwartych pytań badawczych. 
Problem główny:

Jakie uwarunkowania edukacyjne wpłynęły na kształtowanie postaw innowacyjnych menedżerów?

Problemy szczegółowe:

1. Jak badani menedżerowie interpretują swoją edukację?

2. Jakie czynniki charakteryzują ich edukację? Które z tych czynników uważają za szczególnie ważne i dlaczego?

3. Jakie doświadczenia edukacyjne posiadają badani menedżerowie?

4. Jakie czynniki edukacyjne występują $\mathrm{w}$ ich środowisku pracy?

5. Jakie komponenty są charakterystyczne dla kompetencji innowacyjnych menedżera?

6. Jakie czynniki edukacyjne wpłynęły na kompetencje innowacyjne menedżerów?

7. Jak menedżerowie postrzegają swoją edukację do twórczości i innowacji?

\section{Metody i techniki badawcze}

Zastosowałam metodę biograficzną (metodę opowiadanego życia) ${ }^{6}$, technikę wywiadu narracyjnego (według założeń koncepcyjnych F. Schutze) oraz dwa narzędzia: dyspozycje do jakościowego wywiadu narracyjnego oraz zmodyfikowany graficzny diagram koła wywodzący się z metody Koła Shalita, które zastosowalam jako narzędzie wspomagające technikę wywiadu. Nie zastosowałam metody Koła Shalita w jego pełnej wersji (jako metody badawczej), lecz wykorzystałam jedynie jej elementy jako narzędzie uzupełniające i wzbogacające technikę wywiadu. Narzędzie to pomogło badanym wyodrębnić i porangować czynniki charakterystyczne dla ich edukacji. Graficzna forma koła pozwala na obiektywizację procesu doboru i selekcjonowania poszczególnych czynników przez badanych oraz umożliwia porządkowanie pojęć i koncentrację na wybranych indywidualnie aspektach. Technika ta ułatwiła badanym podjęcie refleksji nad zagadnieniami, jak również pozwoliła na wprowadzenie dodatkowych danych do analizy. Technikę zastosowałam zgodnie z zaleceniami metodycznymi Shalita poprzez postawienie badanemu pytania otwartego i możliwość swobodnej interpretacji zarówno pytania, jak i sposobu wykorzystania danego narzędzia (koła graficznego).

\section{Kategorie analityczne}

Kategorie analityczne wyłaniałam, analizując uzyskane informacje dotyczące nie tylko przebiegu ich edukacji czy kariery zawodowej, ale także dane o przekonaniach, postawach, sposobach wartościowania, percepcji siebie i otaczającej rzeczywistości. Zdobyta wiedza była współtworzona i konstytuowana przez badanych. Zebrane dane narracyjno-biograficzne interpretowałam, poddając je analizie rekonstrukcyjnej, która wykroczyła poza bezpośredniość wypowiedzi badanych menedżerów. W celu odtworzenia struktur generujących indywidualne znaczenia

${ }^{6}$ Metoda opowiadanego życia (life story method) to metoda, w której relacja badanej osoby odnosi się bezpośrednio do doświadczeń życiowych związanych z tymi aspektami życia, które chce zinterpretować badacz (Giza, 1991, s. 108). 
i sensy nadawane przez moich rozmówców, w odniesieniu do własnej biografii utworzyłam kategorie, które posłużyły mi do analizy danych i formułowania wniosków. W toku analizy zebranych danych odkrywałam te wątki w narracjach menedżerów, które posłużyły mi do sformułowania kategorii analitycznych. Wyodrębniłam trzy główne kategorie analityczne oraz podkategorie:

I. Doświadczenia edukacyjne menedżerów:

1. Rozumienie edukacji w interpretacji badanych,

2. Czynniki charakteryzujące edukację badanych,

3. Doświadczenia w drodze edukacyjnej:

- Wydarzenia przełomowe,

- Wyzwania,

- Motywacje,

- Niezależność i poczucie autonomii,

- Osoby znaczące.

II. Edukacja w środowisku pracy:

1. Czynniki charakteryzujące edukację $\mathrm{w}$ środowisku pracy,

2. Percepcja kultury i klimatu organizacyjnego z perspektywy menedżerów,

3. Edukacja przez uczestnictwo w programie Zarządzanie Innowacyjne.

III. Kształtowanie kompetencji innowacyjnych menedżerów:

1. Sylwetka innowacyjnego menedżera w interpretacji badanych,

2. Edukacja do twórczości i innowacji.

W analizie i interpretacji materiału empirycznego dokonuję analizy subiektywnej zawierającej jednak pewne obiektywne aspekty wynikające $\mathrm{z}$ wiedzy o badanych: np. poziom i rodzaj posiadanego wykształcenia, pełnione stanowisko i miejsce pracy, uczestnictwo bądź nie w programie "Zarządzanie innowacyjne”. W interpretacji wywiadów przyjmuję podejście ad hoc (Kvale, 2004, s. 195) będące podejściem eklektycznym, w którym można wykorzystać różnorakie podejścia do tekstu wywiadu?

\section{Dobór próby i charakterystyki menedżerów}

Spośród grupy menedżerów uczestniczących w I etapie badań wyłoniłam 15 osób, z którymi przeprowadziłam wywiady. Dobór celowy, który zastosowałam, polegał na przyjęciu czterech kryteriów doboru:

- różne miejsca pracy,

- innowacyjność menedżerów (I etap badań),

- uczestnictwo lub nieuczestniczenie w programie „Zarządzanie Innowacyjne",

- chęć udziału w badaniu.

${ }^{7}$ Podejście to umożliwia powiązanie zarówno metody analizy tekstów, jak i metod ilościowych po to, by wydobyć sens różnych partii materiału. W ramach tego podejścia analizuję dane, wykorzystując kategoryzację sensów, która polega na zakodowaniu wywiadu na kategorie. W myśl tego podejścia (za: Kvale, 2004, s. 195) niektóre dłuższe wypowiedzi redukuję do prostszych kategorii, takich jak ,plus” lub „minus”, wskazujących na pojawianie się lub nie fenomenu. Można również zredukować wypowiedzi do pojedynczej skali od 1 do 5, aby np. wskazać natężenie fenomenu. 
Wśród badanych menedżerów 6 osób stanowiły te nieuczestniczące $\mathrm{w}$ programie „Zarządzanie innowacyjne” oraz 9 osób w nim uczestniczących. W badaniu wzięło udział 11 mężczyzn i 4 kobiety, wiek badanych kształtował się pomiędzy 25 a 58 rokiem życia, wszystkie osoby posiadały wyższe wykształcenie. W kategorii rodzaj wykształcenia 8 osób posiadało wykształcenie ekonomiczne, 6 humanistyczne oraz 1 osoba wykształcenie techniczne.

\subsection{Biografie innowacyjnych menedżerów}

Analiza biografii edukacyjnych menedżerów pozwoliła mi poznać ich indywidualne biografie edukacyjne. W toku narracji menedżerowie opowiadali o sobie, o tym, co jest dla nich ważne, interesujące, o spotkaniach i relacjach z ważnymi dla nich ludźmi, o przełomowych wydarzeniach, które wpłynęły na ich edukację, rozwój, innowacyjność. Nadawali wspominanym wydarzeniom znaczenia i jakości. Uzupełnianie graficznego koła pomogło moim rozmówcom wyodrębnić i powartościować ważne dla nich obszary edukacji i czynniki edukacyjne oraz określić emocjonalny i wartościujący do nich stosunek. W niniejszym tekście przedstawiam tylko wybrane konteksty biograficzne, odnosząc je - użytek tej pracy - do problemów badawczych i wyodrębnionych kategorii analitycznych. Nie ukazuję tu indywidualnych biografii poszczególnych menedżerów.

\subsubsection{Interpretacja własnej edukacji}

Badani rozumieją swoją edukację bardzo szeroko, jako niezwykle ważną, nieodłączną sferę życia, która tak ściśle splata się ze wszystkimi innymi obszarami życia, że niekiedy trudno im było oddzielić ją jako odrębną kategorię. Wskazują na to przykładowe wypowiedzi: życie to edukacja (Bernard K.), praca to edukacja (Marek N.). Można zauważyć, że biografie edukacyjne menedżerów mają charakter „linii renesansowej” (Dubas, 2005), obejmującej wiele zakresów ich aktywności życiowej. Opisane na kołach graficznych obszary charakteryzujące edukację badanych ukazują szeroki wachlarz czynników: podmiotowe, społeczne, rodzinne i zawodowe. Wyodrębniając i rangując czynniki edukacyjne na kole graficznym, za najważniejsze (oznaczone rangą 1) menedżerowie uznali: podnoszenie kwalifikacji, wykształcenie, rodzina-status, praktyczne wykorzystanie wiedzy, wiedza zdobywana jednocześnie z praktyką, chęć sprostania wymaganiom firmy, otwartość na przemyślenia, myślenie, chęć pogłębiania wiedzy, nowość, nowe wyzwania, praca, wiedza ogólna, łatwość uczenia się, filozofia życia, znajomość psychologii. Spośród wymienionych jedne wskazują na praktyczne podejście do edukacji: np. jako drogi do uzyskania wyższego statusu społecznego, 
inne na traktowanie jej jako narzędzia do rozwijania i poznawania siebie oraz otaczającego świata lub jako sposób na realizowanie ambicji. Edukacja to, według kilkorga badanych, także postawa życiowa manifestująca się przez gotowość do permanentnego uczenia się i rozwoju: czerpania wiedzy i doświadczeń z każdej sytuacji i wydarzenia, z własnych sukcesów i porażek, a także od innych ludzi. Tę postawę można określić jako kompetencję edukacyjną (Dubas, 2005), która jest wrażliwa na kształcenie i rozwój, i tak też postrzegana jest przez badanych. Znamienny w wypowiedziach większości rozmówców był początkowy brak skojarzeń ze szkołą. Pojęcie „edukacja” interpretowane było w pierwszych wypowiedziach najczęściej jako: rozwój, poznawanie, doświadczanie życia, świata i siebie lub jako narzędzie do zdobycia pracy czy awansu. Edukacja rozumiana jako „wykształcenie” opisywana była przez większość badanych dopiero w dalszych fazach wypowiedzi, choć wyraziście podkreślane było znaczenie i waga tego obszaru życia. Taka kolejność skojarzeń i wypowiedzi wynika z wysokiej rangi edukacji nieformalnej nadawanej przez badanych, a szczególnie takim jej aspektom, jak: uczenie się przez doświadczenie, przez wykonywanie zadań zawodowych, rozwiązywanie problemów i konfliktów, pracę w określonym środowisku, podejmowanie wyzwań. Zdaniem większości badanych taki rodzaj uczenia się był jednym z głównych źródeł kształcenia i rozwijania ich kompetencji menedżerskich. Jest on, zdaniem badanych, silnie uwarunkowany podmiotowo i wynika z określonej postawy wobec edukacji, życia, a także siebie. Postawa ta jest jednak kształtowana poprzez czynniki zewnętrzne: np. rozdaje wykonywanych zadań, posiadany zakres odpowiedzialności, pracę w określonym klimacie. Opowiadając o swojej edukacji, badani wskazali na wszystkie typy uczenia się (por. Schulze, 1985, za: Nittel, 1991), co świadczy o wysoko rozwiniętych kompetencjach edukacyjnych badanych. W narracjach biografie edukacyjne przeplatały się z biografią zawodową. Według badanych, to zadania zawodowe wyznaczają ich aktualną ścieżkę edukacyjną, która pełni w tym układzie funkcję podrzędną: uczą się tego, co w danym momencie jest im potrzebne do lepszego wykonywania zadań. Edukacja jest więc wynikiem rozwoju zawodowego badanych (por. Nowacki, 2004). Istotnym obszarem edukacji menedżerskiej wskazanym przez badanych jest także edukacja pozaformalna (kursy, szkolenia), która zapewnia szybki i stosunkowo łatwy dostęp do wiedzy. Z perspektywy zawodu menedżera badani uznali, że to, czego nauczyli się „W szkole” (także studia wyższe), poza wiedzą ogólną, stanowi bazę merytoryczną pomocną w wykonywaniu zadań profesjonalnych głównie dla osób z wykształceniem ekonomicznym bądź technicznym, które wykorzystują nabytą wiedzą bezpośrednio. „Bycia” menedżerem nie nauczyli się jednak w procesie kształcenia formalnego. Wyjątek stanowią tu trzy osoby spośród badanych, które twierdzą, że używają wyuczonych na studiach umiejętności. Są to absolwenci: pedagogiki (wydział nauk o wychowaniu, obecnie dyrektor banku, Dawid O.) oraz etnologii i antropologii kulturowej (Marek N., obecnie prezes firmy szkoleniowej, oraz Dariusz K. menedżer Działu ds. Edukacji). Pomimo to 
studia wyższe mają dla badanych ogromną wartość: poszerzyły zakres posiadanej wiedzy i umiejętności, horyzonty i światopoglądy, otworzyły na nowe możliwości, rozwinęły relacje interpersonalne poprzez uczestnictwo w społeczności akademickiej. Pęd do wiedzy jest jednak, według większości badanych, cechą, którą nabyli już wcześniej, w dzieciństwie. Studia umocniły tylko ich postawy edukacyjne. Dla kilkorga (3 osoby) badanych okres studiów stanowił także „poletko doświadczalne" przygotowujące do pełnienia funkcji menedżerskich poprzez aktywną działalność w samorządzie studenckim. Dla większości badanych podjęcie studiów było czymś oczywistym, naturalną drogą do osiągnięcia czegoś w życiu, sukcesu, samodzielności. Świadczy to wysokich aspiracjach edukacyjnych badanych, ukształtowanych przez rodzinę, środowisko, w którym dorastali, a także wynikających $\mathrm{z}$ ich predyspozycji podmiotowych (zdolności poznawcze, intelektualne). Studia wyższe tylko częściowo rozwinęły potrzeby edukacyjne badanych, rozwija je, ich zdaniem, przede wszystkim praca, a także, według dwojga badanych - życie w określonym środowisku i społeczeństwie. Badani menedżerowie są ludźmi o dużych potrzebach edukacyjnych, co świadczy o ich wysokiej świadomości edukacyjnej. Szkoła (edukacja formalna) rozwinęła w badanych: umiejętność uczenia się, myślenia, zapamiętywania, rozwiazywania problemów oraz poszerzyła horyzonty i rozbudziła ciekawość poznawcza. Dostarczyła także kwalifikacje, które otworzyły drogę do awansu społecznego i dalszej edukacji.

\subsubsection{Istotne doświadczenia edukacyjne}

Chcąc uzyskać odpowiedź na to pytanie badawcze, poprosiłam menedżerów o zrelacjonowanie przebiegu swojej ścieżki edukacyjnej i wyeksponowanie najważniejszych ich zdaniem doświadczeń. Opowiadając o swoich doświadczeniach edukacyjnych, związanych ze zdobywaniem wykształcenia, badani wskazywali na istotną rolę ich indywidualnych cech, predyspozycji i postaw, które wpływały na przebieg uczenia się i zdobywania wykształcenia. Jako główne badani wymienili: wytrwałość, wysiłek, systematyczność, poświęcenie, upór, otwartość na przemyślenia i poglądy innych ludzi, zdolność szybkiego uczenia się, dobrą pamięć, umiejętność kojarzenia, „wielofunkcyjność”. Te podmiotowe uwarunkowania do uczenia się badani, jak twierdzą, posiadali już we wczesnym dzieciństwie, niektóre z nich zostały ukształtowane przez rodziców, inne stanowią, ich zdaniem, cechy wrodzone. Można zauważyć, że niektóre z wymienionych cech charakteryzują także postawę twórczą (zob. Nęcka, 2001; Popek, 2001.), co wskazuje na predyspozycje twórcze badanych osób.

Większość menedżerów wskazała na znaczenie silnie rozwiniętej wewnętrznej motywacji do rozwoju i uczenia się, przejawiającej się jako: pęd do wiedzy, chęć uzupełniania informacji, chęć podążania za galopującymi zmianami, chęć 
rozwoju, chęć pokonywania trudności i podejmowania wyzwań, chęć wybicia się. Według pięciorga badanych to rodzice, a zwłaszcza matki, zaszczepili w nich tę wewnętrzną motywację poprzez: zachęcanie i motywowanie do nauki, podnoszenie poprzeczki i dawanie wsparcia. Środowisko rodzinne odegrało rolę także w kształtowaniu postaw twórczych poprzez stymulowanie do poznawania otaczającego świata, rozwijania siebie, odpowiedzialności (por. Amabile, 1983; Sołowiej, 1987; Csikszentmihalyi, 1966). Te początkowe ambicje rodziców stopniowo przekształciły się w postawę edukacyjną. Kilkoro badanych wspominało, że w pewnym momencie zdali sobie sprawę, że uczą się dla siebie, swojego rozwoju i przyszłości, co jedna z badanych (Mariola W. - prezes firmy produkcyjnej) określiła jako „sprzężenie zwrotne”: jedno jest zależne od drugiego: czym bardziej się rozwijam, tym większa mam potrzebę uczyć się kolejnych rzeczy. Motywacja wewnętrzna odgrywa także ważną rolę w twórczym rozwoju jednostki: $\mathrm{z}$ jednej strony stymuluje do twórczości, z drugiej ją generuje (zob. Amabile, 1983). Takie stwierdzenia jak: motywuje mnie to co mnie otacza i tak naprawdę ludzie (Bożena O.) czy: ucze się aby lepiej zrozumieć, to co mnie otacza - świadczą o postawach otwartych i ciekawości poznawczej, które także charakteryzują ludzi twórczych. Szkoła, zdaniem badanych, w niewielkim stopniu rozwijała wewnętrzną motywację do uczenia się, która wynikała raczej z ciekawości poznawczej lub stymulacji rodziny niż działań dydaktyczno-wychowawczych pedagogów. Niektórzy badani przedstawiali rolę motywacji zewnętrznej do uczenia się w kontekście społecznym jako przejawiającej się w chęci wybicia się, polepszenia statusu rodziny (w przypadku studiów wyższych), ambicji by być kimś. Według Grzegorza T. jego proces uczenia się to jest stałe balansowanie pomiędzy „chcę” a ,muszę”, a te dwa rodzaje motywacji przeplatają się. Dla trojga badanych czynnikiem motywującym jest także rywalizacja i chęć liderowania. Rozwinięta wewnętrzna motywacja do uczenia się i rozwoju charakteryzująca badanych menedżerów wiąże się z samorealizacją, a więc twórczością bez dzieła, skierowaną na samego siebie: przekształcaniem i kreowaniem siebie. Rys samorealizacji widoczny jest w biografiach niemal wszystkich badanych, co także wskazuje na postawy twórcze.

Ważne doświadczenia w edukacyjnych biografiach badanych związane są z momentami przełomowymi, którymi były między innymi: zmiana szkoły, wyjazd do szkoły średniej do innego miasta, wyjazdy zarobkowe za granicę w szkole średniej, matura, wybory kierunków kształcenia, podjęcie pierwszej pracy, praca, a także porażki i sukcesy. Dwie osoby wskazały na podjęcie studiów po wielu latach przerwy w nauce jako momentu przełomowego (momentem przełomowym byt wstyd, że dorosły facet nie ma wyższego wykształcenia (Bernard K., menedżer w firmie farmaceutycznej)). Charakterystyczne dla wypowiedzi badanych jest poszukiwanie momentów przełomowych raczej w sobie niż w wydarzeniach zewnętrznych, co badani określali jako momenty, w których dokonywała się w nich wewnętrzna przemiana. Badani określali te sytuacje jako: przełamywanie barier wewnętrznych, usamodzielnienie, wzięcie odpowiedzialności, podjęcie wyzwa- 
nia; poczucie, że pewne rzeczy zależą ode mnie. Te wewnętrzne przemiany związane były z przewartościowaniem, odkryciem nowych możliwości, spojrzeniem z innej perspektywy, uświadomieniem własnej autonomii, poczuciem samodzielności za siebie i swoje życie - nie zawsze powiązane były z jakimś konkretnym wydarzeniem. Odegrały one, zdaniem badanych, istotną rolę w kształtowaniu ich postaw, tożsamości, osobowości. Doświadczanie przełomu wewnętrznego związane jest z transgresją i twórczością. Jak pisze J. Kozielecki, ludzie dążący do ciągłego przekraczania granic własnych osiągnięć, koncentrujący swoją uwagę na przyszłości i wykazujący większą tolerancję wobec ryzyka stosują heurystyczne strategie wyboru i charakteryzują się silną autonomią (Kozielecki, 1987, s. 150). Dla takich osób środowiskiem sprzyjającym działaniom transgresyjnym i twórczym jest wolność i możliwość swobody wyboru. Znaczenie tych warunków jako stymulujących postawy twórcze wielokrotnie było podkreślane przez badanych. Ponieważ momenty przełomowe są sytuacjami granicznymi (zob. Kozielecki, 1987), które wiążą się z przewartościowaniem, a więc zaadaptowaniem nowej struktury wartości i przekraczaniem aktualnie posiadanych dyspozycji, stanowią sytuacje edukacyjne, w których jednostka uczy się wartościować i działać w nowy dla siebie sposób.

Związane z momentami przełomowymi doświadczenie poczucia niezależności i autonomii stanowiło ważną kategorię w biografiach edukacyjnych moich rozmówców. Prawie wszyscy badani (poza trzema osobami) akcentowali wpływ tego doświadczenia na przebieg dalszej edukacji i motywacje do uczenia się, a także na przebieg kariery zawodowej i kształtowanie postawy innowacyjnej. Pierwsze odczucie niezależności pojawiło się w różnych okolicznościach i okresach ich życia (np. swobodne wakacje u babci na wsi, samodzielny wybór szkoły średniej, studiów czy kierunku dalszego kształcenia). Jedna z badanych tak opisuje to doświadczenie: byt taki moment, kiedy miałam 11-12 lat, kiedy rodzice nie kontrolowali tego co robię i ja sama zaczęłam narzucać sobie pory wstawania i powrotu do domu. To była dla mnie szkoła przetrwania [...]. Ale od tej pory mam w sobie to poczucie niezależności i wiem, że sama o sobie decyduję (Anna B.).

Niektórzy badani podkreślili, że od momentu pojawienia się tego doświadczenia - poczucia własnej niezależności - czują się osobami samodzielnymi i samoodpowiedzialnymi. Pięcioro badanych uważa, że poczucie niezależności towarzyszyło im od wczesnego dzieciństwa (przedszkole, szkoła podstawowa), co przejawiało się np. w chęci liderowania, wyrażaniu swojego zdania. Szkoła jednak nie tolerowała niezależności, co w przypadku trojga badanych objawiało się buntem i konfliktami z kadrą nauczycielską. W odniesieniu do pracy - niezależność i wolność stanowią dla badanych wyjątkowo cenione wartości, które warunkują zarówno uczenie się, jak i twórczość. Liczne badania nad twórczością wskazują, że niezależność i autonomia są jednymi z kluczowych warunków twórczości, jak również są istotne we wdrażaniu innowacji. Są także warunkiem działań transgresyjnych, jak pisze J. Kozielecki: ,transgresja to zrealizowana wolność, a wolność 
to zrealizowana transgresja" (Kozielecki, 1987, s. 284). Wyniki I etapu badań (badania ilościowe) ujawniły, że menedżerowie przejawiają znacznie wyższy poziom nonkonformizmu niż pozostali pracownicy. Można zatem przyjąć, że czynnik ten jest jednym z komponentów kompetencji innowacyjnej.

Z kategorią autonomii wiąże się także kolejna: wyzwania. Jest ona istotna dla badanych i silnie wiąże się ze zmianą, innowacjami, a także z motywacją. Wyzwania, zdaniem większości badanych, stanowią integralną część ich codziennej pracy, kilka osób stwierdziło, że praca sama w sobie stanowi dla nich wyzwanie, zarówno ta aktualna, jak i podjęcie pierwszej pracy, jej poszukiwanie. W drodze edukacyjnej wyzwania stanowiły dla badanych największą motywację do pokonywania trudności, rozwoju i dalszej edukacji. Wyzwania rozumiane były także jako cele do spełnienia, których osiągnięcie daje dużo radości i satysfakcji. Badani z dumą opowiadali o podjętych wyzwaniach, pokonywanych trudnościach, mierzeniu się ze swoimi lękami i słabościami. Wyzwania wiążą się także, zdaniem badanych, z odpowiedzialnością: im wyższe poczucie odpowiedzialności, tym większa motywacja do podejmowania wyzwań. Postawy otwarte wobec podejmowania wyzwań jeszcze raz wskazują na inklinacje w kierunku osobowości transgresyjnej badanych. Dzięki działaniom transgresyjnym, jakie stanowią wyzwania, jednostka może powiększać swoje terytorium, wzbogacać doświadczenie, poszerzać granice wolności, a także zwiększać swoją kontrolę nad zespołami ludzkimi (Kozielecki, 1987, s. 60). Pokonywanie wyzwań może więc wskazywać drogę rozwoju człowieka. Podejmowanie wyzwań jest także przejawem postawy twórczej, która według S. Popka manifestuje się między innymi ,gotowością do przekształcania świata, zjawisk, rzeczy, własnej osobowości” (Popek, 2000, s. 27). Ten rodzaj zachowań wiąże się zarówno z komponentem działaniowym, jak i motywacyjnym postawy twórczej i wyraża jej aktywny stosunek do świata. Wyzwania są kategorią zachowań heurystycznych, a więc opierają się na przetwarzaniu informacji z wykorzystaniem myślenia dywergencyjnego, wyobraźni i intuicji (Popek, 2001). Pokonywanie wyzwań jest także powiązane z postawą innowacyjną - każda innowacja ze względu na swoją nowość jest wyzwaniem, a jej wdrażanie powoduje często konieczność pokonywania nieprzewidzianych trudności i rozwiązywania niestandardowych problemów. Pokonywanie wyzwań stanowiło jeden z istotnych czynników edukacyjnych w kształtowaniu postaw innowacyjnych badanych menedżerów, co było podkreślane przez badanych.

Wpływ na edukację i rozwój badanych miały także autorytety (osoby znaczące), nie dotyczy to jednak wszystkich. Znamienne w wypowiedziach kilkorga menedżerów było postrzeganie autorytetu niezogniskowanego w jednej konkretnej osobie, lecz rozumianego jako cechy, postawy, umiejętności czy osiągnięcia różnych ludzi. Wśród konkretnych osób badani uznawali za autorytety tych, którzy pokazali im drogę do niezależności, autonomii, pomogli w budowaniu ich własnej tożsamości. Byli to, w przypadku kilkorga badanych, rodzice, którzy ukształtowali w nich aspiracje i samodzielność, a także inne osoby, od których badani 
mogli uczyć się tego, czego sami potrzebowali do dalszego rozwoju i edukacji. Zaledwie dwoje badanych wskazało na nauczycieli, u których cenili podmiotowe podejście do ucznia i nauczenie samodzielnego myślenia. Młody menedżer (Marcin C.) stwierdził, że autorytetami są dla niego jego podwładni, bo od nich się uczy. Kilkoro badanych wskazało także na znaczącą rolę przełożonego, który pełni rolę mentora: poprzez swoją osobowość, osiągnięcia, styl relacji, innowacyjne podejście do zarządzania: fascynuje mnie jego innowacyjność (Mariola W.). Z punktu widzenia stanowiska menedżerskiego mentoring może stanowić ważny czynnik edukacyjny - menedżer zawsze bowiem jest osobą, która świadomie lub nie - modeluje zachowania innych uczestników organizacji. Z tej perspektywy warunkiem kształtowania klimatu innowacyjnego w organizacji są właśnie postawy innowacyjne menedżerów. Wyniki I etapu badań pokazały, że klimat innowacyjny nie zależy od postaw twórczych pracowników, lecz właśnie menedżerów, którzy ten klimat kształtują. Także w badaniach nad twórczością często podejmowany bywa problem modelowania i mentoringu (Amabile, 1983b; Stasiakiewicz, 1999; Sołowiej, 1997 i in.). Badacze zwracają uwagę na kreatogenną rolę między innymi takich czynników w relacji mentor-podopieczny, jak: podmiotowe traktowanie, zachęcanie do niezależności, wysokie wymagania i pokazanie możliwości ich realizacji, entuzjazm, partnerskie relacje i satysfakcjonujący kontakt interpersonalny (za: Stasiakiewicz, 1999, s. 123).

\subsubsection{Czynniki o charakterze edukacyjnym w środowisku pracy}

Wykonywany zawód oraz środowisko pracy mają dla wszystkich badanych wymiar edukacyjny, zwłaszcza w kształtowaniu ich kompetencji menedżerskich i innowacyjnych. Dla ponad połowy menedżerów pojęcia ,praca” i „,edukacja” są wręcz tożsame. Niektórzy zauważają jednak, że edukacyjne oddziaływanie środowiska pracy jest w dużym stopniu uwarunkowane podmiotowo: to jednostka sama decyduje, ile czerpie $\mathrm{z}$ danego środowiska i napotykanych sytuacji oraz czy to, co zyskuje ma dla niej charakter edukacyjny i w jakim stopniu. Obok istotnych uwarunkowań podmiotowych, badani wskazali na edukacyjny charakter takich wymiarów organizacji, jak: specyfika firmy, styl zarządzania, kultura i klimat pracy, nastawienie wobec innowacji i zmian. Ważny jest także rodzaj i zakres pełnionych zadań menedżerskich, bowiem ogromne znaczenie w kształtowaniu postaw innowacyjnych odgrywa, zdaniem badanych, uczenie się poprzez rozwiązywanie problemów i zadań zawodowych. Zwraca uwagę, że wszyscy badani wskazali na znaczącą rolę edukacji nieformalnej i pozaformalnej w kształtowaniu ich kompetencji menedżerskich. Oto najważniejsze czynniki edukacyjne wskazane przez menedżerów w miejscu pracy (zanotowane przez rozmówców na graficznym diagramie koła): 
- nauka przez podejmowanie decyzji i analizę ich efektów,

- docenienie innowacyjnego podejścia do zarządzania,

- umiejętność budowania relacji z ludźmi,

- nowe spojrzenia,

- styl zarządzania,

- przestrzeń,

- wolność,

- zdobywanie nowych doświadczeń,

- wiedza,

- moja 7-letnia praca w banku na pewno spowodowała rozwój w sferze zawodowej. Uczestniczę w wokandach sądowych, na przesłuchaniach. Jestem za stary na to, aby skończyć prawo,

- kreatywność,

- podwyższanie bieżących kwalifikacji,

- doświadczenie zawodowe,

- wybór przyszłego zajęcia,

- wypracowanie pewnego modelu strategii działania.

Menedżerowie uczestniczący w programie „Zarządzanie innowacyjne” bardzo cenią sobie innowacyjny model zarządzania i kreowane w ramach niego wartości, zwłaszcza takie jak: wolność, zespołowość, elastyczność i otwartość. Elastyczna struktura organizacyjna oraz zmienność w pełnieniu ról organizacyjnych powoduje stały proces uczenia się. Charakterystyczną cechą tej organizacji jest także stałe wprowadzanie zmian i innowacji, które także wpływają na konieczność rozwijania coraz to nowych kompetencji, a także konieczność podejmowania wyzwań. Oprócz czynników wymienionych na kole graficznym, a determinujących ich uczenie się w organizacji, badani wskazali także na:

- możliwość doświadczania powiązaną z własną otwartością, refleksyjnością i chęcią uczenia poprzez obserwację swoich działań,

- uczenie się poprzez współpracę i współdziałanie, pracę zespołową i grupowe rozwiązywanie problemów,

- uczenie się poprzez budowanie relacji,

- zarządzanie ludźmi,

- różnorodność zadań i problemów,

- samodzielność i odpowiedzialność,

- podejmowanie wyzwań i ryzyk,

- doskonalenie zawodowe (kursy, szkolenia i studia podyplomowe).

Charakterystyczne dla wypowiedzi tej grupy menedżerów jest wielokrotne podkreślanie wagi w procesie uczenia się takich wartości, jak: wolność, niezależność, samodzielność. Te czynniki stymulują, ich zdaniem, wewnętrzną motywację, odwagę do podejmowania wyzwań i ryzyk, do stosowania rozwiązań niestandardowych oraz samoodpowiedzialności. Badani zauważają także, że występowanie tych czynników powinno być powiązane $\mathrm{z}$ wyzwaniami i stymulacją 
w kierunku przekraczania granic i barier stawianych przez najwyższy szczebel zarządu organizacji. Organizacja, chcąc promować działania innowacyjne i transgresyjne, musi więc kłaść nacisk na kreowanie kultury i klimatu innowacyjnego. Według badanych uczestniczących w programie „Zarządzanie innowacyjne”, ich organizacja sprzyja kształtowaniu postaw innowacyjnych.

Natomiast menedżerowie nieuczestniczący $\mathrm{w}$ w/w programie podkreślili ważność takich czynników, jak: wiedza, dokształcanie (kursy, szkolenia), uczenie się przez doświadczanie możliwość podwyższania kwalifikacji. Wyżej porangowali praktyczne wymiary sukcesu zawodowego, takie jak: pozycja i prestiż społeczny, bycie w określonym środowisku (Bożena O.), korzyści materialne i materialne (Bernard K., Barbara S.). Równie wysoko menedżerowie Ci cenią sobie także: satysfakcję, kreatywność, samokształcenie. Jedna osoba z tej grupy wskazała na uczenie się poprzez współpracę i umiejętność pracy w zespole jako drugi co do ważności czynnik edukacyjny. Pan Dawid O., menedżer sprawujący od 7 lat stanowisko dyrektorskie w banku, twierdzi, że najwięcej nauczył się, zmieniając branże (handel, gastronomia, krawiectwo, kwiaciarstwo, obecnie: windykacja). Rozwiązując problemy zawodowe, korzysta ze swoich bogatych doświadczeń, które pozwalają mu na szerokie spojrzenie i wykorzystanie różnych możliwości. Pokazuje to raz jeszcze renesansową linię kariery i ścieżki edukacyjnej.

Porównując obie grupy, można zauważyć, że menedżerowie uczestniczący w programie raczej dostrzegają wartości edukacyjne w pokonywaniu wyzwań o charakterze wewnętrznym (pokonywanie własnych barier, przekraczanie siebie) niż kierują się tylko chęcią osiągnięcia sukcesu w wymiarze społecznym, choć to też ma dla nich znaczenie.

\subsubsection{Kompetencje innowacyjne}

Kolejna faza wywiadu dotyczyła kompetencji innowacyjnych (choć przebieg każdej rozmowy był inny). Prosiłam badanych, by ustosunkowali się do pytania: czy uważasz się za innowacyjnego menedżera?, a następnie: jakie cechy charakteryzują innowacyjnego menedżera?

W odniesieniu do pierwszego pytania troje z rozmówców wyraziło swoje wątpliwości. Pani Bożena O. na przykład nie uważa się za menedżera innowacyjnego, lecz przedsiębiorczego i sprytnego, co w jej rozumieniu jest czym innym niż innowacyjność, która jej zdaniem wiąże się z byciem kimś wybitnym, twórczym. Pani kierownik posiada jednak w środowisku opinię osoby innowacyjnej właśnie z powodu swojej wyjątkowej przebojowości i skuteczności w działaniu. Potrafi ona, zdaniem współpracowników, pokonać wszystkie przeszkody, zawsze osiąga cel. Te opinie świadczą o takim właśnie potocznym rozumieniu kompetencji innowacyjnych menedżera. 
Pan Bernard K. także postrzegany jako innowacyjny menedżer uważa natomiast, że: Każda innowacyjność opiera się na pieniadzach. Ja nazywam to zmianami, a nie innowacyjnością. To musi wynikać ze strategii, z programów rozwojowych. Dla mnie to ulepszanie procedur, wprowadzanie nowego sposobu zarzadzania. Ulepszanie, zmiany, polepszanie - a nie innowacje. Większość rzeczy to tylko ulepszanie. Innowacyjne zarzadzanie to wprowadzanie nowych trendow. Ja jestem kreatywny, umiem sobie radzić w kazdych warunkach, ale zarzadzanie innowacyjne to coś więcej, moge powiedzieć, że po części jestem innowacyjnym menedi̇erem.

Innowacyjny menedżer, zdaniem pana Bernarda K., powinien jedynie: realizować misje i strategie. Wypetniać rzetelnie obowiazki, aby satysfakcja z jego pracy przełożyła się na personel. Robić „, swoje” dobrze, dla firmy, dla pracowników.

Także pani Bożena O. miała wątpliwości nad odpowiedzią: Nie wiem czy takie osoby istnieją. Człowiek nie jest $w$ stanie umieć wszystkiego. Zawsze jest coś kosztem czegoś. Jeśli coś zyskujesz, to coś innego zostaje ci w tym momencie zabrane. Np.jesteśmy albo umysłem humanistycznym albo ekonomicznym. Należy się wyspecjalizować $w$ danym kierunku. Najlepiej jest jak zespół realizuje razem pewne cele, kazdy jest innym specjalista $w$ tym zespole oraz wspieraja się nawzajem. Innowacyjność to siła tkwiąca $w$ takim zespole.

Kolejna wypowiedź świadczy o pewnej trudności w samoocenie: Mnie jest to trudno ocenić, bo jest mowa o mnie. Staram się nie budować swojego autorytetu na pozycji, tylko traktować ludzi, z którymi pracuje jako partnerów. Nie wykorzystuję pozycji w pracy do budowania autorytetu. Staram się budować ten autorytet na tym jaki jestem, w jaki sposób podejmuje decyzje, jakie one mają efekty.

Pozostali menedżerowie uważają się jednak za innowacyjnych menedżerów. Podkreślali, że innowacyjny menedżer powinien być twórczy, kreatywny. Pytani jednak o twórczość w zarządzaniu, zdecydowanie chętniej używali pojęcia ,innowacyjność”. Wypowiedź pani Marioli W. jest przykładem takiej opinii: W zarzadzaniu trudno mówić o twórczości, twórczość jest mi obca. Coś powstaje z niczego. Innowacyjność to ulepszanie, jest baza, z której się wychodzi, modyfikuje. Ja wole bardziej słowo innowacyjność. Ja jestem innowacyjna. Widze to po swoich znajomych, mam potwierdzenie z otoczenia, że inaczej podchodze do tematu. Innowacyjność to przebojowość, zdolność rozwiązywanie problemów w inny sposób.

Pozostali menedżerowie innowacyjnego menedżera scharakteryzowali w następujący sposób:

Innowacyjny manager to ktoś otwarty, przebojowy. Wszystko musi być podparte jakąś wiedza. Dla mnie ważne jest także doświadczenie, nie ten co ma piękne CV. Ludzie, którzy wiedza czego chca i widać to zawzięcie. Potrafia obejść przeszkode, z pomysłami, radzacy sobie z problemami. Aby się przebić w mojej firmie trzeba mieć to coś, to zawzięcie. Jeszcze lepiej jeżeli jest to oparte na wiedzy na dany temat. To jest właśnie kreatywny manager czyli ktoś przebojowy. Ważna jest 
także komunikatywność ale to się wiąże z przebojowością. Jeżeli ktoś nie będzie komunikatywny, to nie będzie przebojowy. Ważna jest ta komunikacja, umiejętność negocjowania, otwartość, umiejętność kadzenia (Dawid O.).

To osoba, która podąża za zmianami, która sama potrafi się w nich odnaleźć i potrafi odnaleźć $w$ nich inne osoby. Trzeba podązać za tym wszystkim, chcieć te zmiany wprowadzać $w$ życie. Ciagle się tym interesować $i$ być na biezaco. Nie można teraz czegoś poznawać po wierzchu. Nie wiem czy można się tego nauczyć. To raczej z samego siebie wyptywa. Chce i po prostu to robię. Trzeba znać pewne procedury $w$ pracy i posiadać pewna wiedze wzorcową. Teraz na zmiany nie ma dużo czasu, trzeba za nimi szybko podażać (Sławomira W.).

To taki, który nie poprzestaje na tym co ma, że coś osiagnąt. Szuka nowych pól do zagospodarowania. Cały czas ulepsza i zmienia czynności, procedury, które wykonywat do tej pory. Poszukuje cały czas nowych rozwiazań nie poprzestaje na tym co ma, na jednym rozwiazaniu tego samego problemu. Szuka korzystniejszych rozwiazań dla siebie, innych ludzi, organizacji (Marek N.).

Poszukujacy, ktoś kto rozwiąuje problemy nie w sposób standardowy. Nie poszukuje w ksiażce jak rozwiazać dany problem, ale korzysta z wiedzy i nagina ta wiedzę do swojego miejsca pracy, do konkretnego problemu, by w sposób bardzo aktywny wykorzystywać to (Grzegorz T.).

Otwarty, konsultuje ważne decyzje z zespotem/dziatem, jest otwarty na propozycje pracowników, umie dyskutować i nie zamyka się tylko na swoje poglądy, dobrze przygotowany merytorycznie. To osoba opanowana, umiejaca podejmować decyzje słuszne $w$ jego mniemaniu, wystrzegać się decyzji stronniczych, decyzja nie może krzywdzić innych osób. To osoba kreatywna, która umie sama coś wytworzyć, z kilku wersji czy propozycji stworzyć jedna. Daje podwładnym możliwość popetnienia błędu, ponieważ różni ludzie, $w$ różny sposób się ucza $i w$ różnym czasie, pracownik może podjać $w$ danym momencie zła decyzję, błędną. Innowacyjny menadżer powinien być dobrym obserwatorem, łatwo nawiazywać kontakty z innymi ludźmi, być otwarty na ludzkie aspekty życia, ponieważ zawsze może się coś wydarzyć. Powinien pomagać pracownikom w rozwiazywaniu problemów, wspierać ich: jeśli sam nie dasz rady to ja ci pomoge. Menadżer powinien umieć rozmawiać zarówno ze sprzątaczka jak i z prezydentem. Umieć szybko podejmować decyzje, szybko reagować. Potrafi brać odpowiedzialność za swoje decyzje, za podwładnych i śledzić ich rozwój: czy zwiększają swój potencjat, czy nadaja się na dane stanowisko. Pracownicy powinni wiedzieć, że każdy robi cośswojego a jednocześnie działaja wspólnie, czyli wytwarzanie poczucia wspólnoty i jednocześnie świadomości ważności pojedynczego działania. Jeśli buduje się zespół to nie może być tak, że jedna osoba jest wyalienowana, jest dobrze kiedy jest jakaś zdrowa rywalizacja, to ludzie zupetnie inaczej ze soba współdziałaja (Dariusz K.).

Wykazuje się tymi cechami co każdy menadżer. Powinien wiedzieć czym się zajmuje jego dziat, jego podwładni po to, aby go odpowiednio przydzielić prace. Kultura osobista, powinien mieć rozwinięte takie planingowe, strategiczne cechy, 
a innowacyjny powinien być w momencie rozwiąywanie konfliktowych sytuacji. Do tego trzeba mieć jakieś predyspozycje genetyczne (Robert G.).

Powinien mieć umiejętność szerokiego spojrzenia na problemy z bardzo różnych stron, świadomość spojrzenia z różnych płaszczyzn-ekonomicznej, duchowej, ludzkiej. Dostosowuje narzędzia pracy, strukture firmy do potrzeb. Ma świadomość efektów tego co chce osiagnąć, jest wizjonerem, buduje drogę dojścia do tego celu. Korzysta z możliwości, zasobów i wiedzy innych osób. Rozwija się caty czas, także duchowo. Otwiera się na inne kultury $i$ doświadczenia innych osób (Adrian L.).

Otwarty na wszelkie pomysty. Człowiek lubiacy zmiany. Te nowe pomysty niosa zmiany. W tym momencie coś jest nie do wykonania ale za jakiś czas tak. Tolerancja na zmianę tak otwartość na zmianę (Patryk W.).

Badani bardzo różnie definiowali ,innowacyjnego menedżera”, określając go jako dobrego menedżera, który rzetelnie wypełnia swoje obowiązki, osobę twórczo rozwiązującą problemy i konflikty, osobę wyjątkową - twórcę, wizjonera, który wprowadza nowe koncepcje i trendy w zarządzaniu. Postrzeganie kompetencji innowacyjnych było więc bardzo szeroko i różnorodnie rozumiane przez badanych. Niektóre cechy charakteryzujące innowacyjnego menedżera wskazali niemal wszyscy badani, są to: otwartość, szerokie spojrzenie na problemy, umiejętność twórczego rozwiązywania problemów i konfliktów, podążanie za zmianami, kreatywność. Innowacyjny menedżer to, zdaniem większości badanych, człowiek przebojowy, ciągle poszukujący, ciągle wprowadzający zmiany i udoskonalenia, komunikatywny i łatwo nawiązujący kontakty z ludźmi, umiejący inspirować podwładnych, słuchać ich opinii i dostrzegać dobre pomysły. Niektórzy wspominają także o umiejętności samodzielnego konstruowania, udoskonalania narzędzi zarządczych. Troje badanych zwróciło uwagę na rozwój osobisty: innowacyjny menedżer świadomie rozwija swoją osobowość, poznaje siebie, pracuje nad swoimi słabymi stronami. Pan Adrian L. zauważył, że jest to osoba, która rozwija się duchowo, co rozumie jako: zwrócenie uwagi nie tylko na czynniki typowo zawodowe ale na spojrzenie w głab siebie, na spojrzenie na drugiego człowieka jako na osobe posiadajaca cechy duchowe. U nas w firmie kładzie się nacisk na indywidualny rozwój pracownika. Rozwój duchowy to sa wartości. Podjęcie decyzji poprzez wartości ekonomiczne przynosi efekty duchowe dla każdego. Zaangażowanie $w$ nowe projekty z innymi krajami przynosi ogromny rozwój duchowy.

Jednocześnie innowacyjny menedżer powinien posiadać typowe cechy „dobrego menedżera": wysoką motywację, umiejętność szybkiego reagowania na nową sytuację, umiejętność podejmowania trudnych decyzji, zorientowanie na osiąganie celów. Cechami wyróżniającymi innowacyjnego menedżera jest także zdaniem badanych: umiejętność szybkiego reagowania na nową sytuację, zorientowanie na ludzi, posiadanie „,miękkich” umiejętności w zarządzaniu ludźmi, w budowaniu zespołu i relacji, wydobywaniu i wykorzystywaniu potencjału ludzkiego. 
Moi rozmówcy w dużym stopniu utożsamiali się z prezentowanymi przez siebie sylwetkami innowacyjnego menedżera, opisując „model” nawiązywali często do swoich doświadczeń, posiadanych cech i umiejętności, sukcesów bądź porażek. Trudność w zdefiniowaniu innowacyjności polega na tym, że to, co jedni nazywają innowacjami lub nawet twórczością, dla innych są to jedynie drobne usprawnienia, udoskonalenia (Bernard K., Bożena O., Barbara K.). Można przyjąć, że ta kategoria wymyka się sztywnej obiektywizacji, jest subiektywna i zależna od perspektywy opowiadającego. Tę prawidłowość zauważyłam już, prowadząc szkolenia dla menedżerów: w pewnym momencie okazywało się, że każdy uczestnik co innego rozumie pod hasłem ,innowacja”. Stąd ważne jest doprecyzowanie pojęć.

Dla uczytelnienia przygotowałam „,model” innowacyjnych kompetencji menedżerskich, opracowując wyciąg z wypowiedzi, co przedstawia poniższa tabela.

Tabela 1. Innowacyjne kompetencje menedżerskie

\begin{tabular}{|c|c|}
\hline $\begin{array}{l}\text { Kompetencje } \\
\text { intrapersonalne }\end{array}$ & $\begin{array}{l}\text { - } \text { otwarty, } \\
\text { - } \text { przebojowy, } \\
\text { - } \text { przedsiębiorczy, } \\
\text { - } \text { sprytny, } \\
\text { - } \text { poznaje siebie, } \\
\text { - } \text { pracuje nad swoimi słabymi stronami, } \\
\text { - } \text { wybitny, twórczy, } \\
\text { - } \text { opypełnia rzetelnie obowiązki, } \\
\text { - umie podejmować decyzje słuszne w jego mniemaniu, wystrzega się de- } \\
\text { - cyzji stronniczych, decyzja nie może krzywdzić innych osób, } \\
\text { - buduje drogę dojścia do tego celu, } \\
\text { - } \text { rozwija się duchowo (w sferze wartości). }\end{array}$ \\
\hline $\begin{array}{l}\text { Kompetencje } \\
\text { interpersonalne }\end{array}$ & $\begin{array}{l}\text { - komunikatywny i łatwo nawiązujący kontakty z ludźmi, } \\
\text { - dobry obserwator, } \\
\text { - } \text { zorientowany na ludzi, } \\
\text { - posiada „miękkie” umiejętności w zarządzaniu ludźmi, w budowaniu ze- } \\
\text { - } \text { umołu i relacji, wydobywaniu i wykorzystywaniu potencjału ludzkiego, } \\
\text { mysły, } \\
\text { - posiada umiejętność negocjowania, } \\
\text { - otwarty, } \\
\text { - korzysta z możliwości, zasobów i wiedzy innych osób, } \\
\text { - konsultuje ważne decyzje z zespołem/działem, jest otwarty na propo- } \\
\text { zycje pracowników, umie dyskutować i nie zamyka się tylko na swoje } \\
\text { poglądy, } \\
\text { otwarty na ludzkie aspekty życia, ponieważ zawsze może się coś wyda- } \\
\text { rzyć, }\end{array}$ \\
\hline
\end{tabular}




\begin{tabular}{|c|c|}
\hline $\begin{array}{l}\text { Kompetencje } \\
\text { interpersonalne }\end{array}$ & $\begin{array}{l}\text { - daje podwładnym możliwość popełnienia błędu, ponieważ różni ludzie, } \\
\text { w różny sposób się ucza i w różnym czasie, pracownik może podjać w da- } \\
\text { nym momencie zła decyzję, błędna, } \\
\text { - pomaga pracownikom w rozwiązywaniu problemów, wspiera ich, } \\
\text { - umie rozmawiać zarówno ze sprzataczka, jak i z prezydentem, } \\
\text { - bierze odpowiedzialność za podwładnych, } \\
\text { - śledzi rozwój podwładnych: czy zwiększają swój potencjał, czy nadają } \\
\text { się na dane stanowisko, } \\
\text { - umie wytwarzać poczucie wspólnoty i jednocześnie świadomość ważno- } \\
\text { - ści pojedynczego działania, } \\
\text { - jeśli buduje się zespół to nie może być tak, że jedna osoba jest wyalieno- } \\
\text { wana, jest dobrze, kiedy jest jakaś zdrowa rywalizacja, to ludzie zupetnie } \\
\text { inaczej ze soba współdziałaja, } \\
\text { - otwarty na inne kultury i doświadczenia innych osób. }\end{array}$ \\
\hline $\begin{array}{l}\text { Kompetencje } \\
\text { twórcze }\end{array}$ & 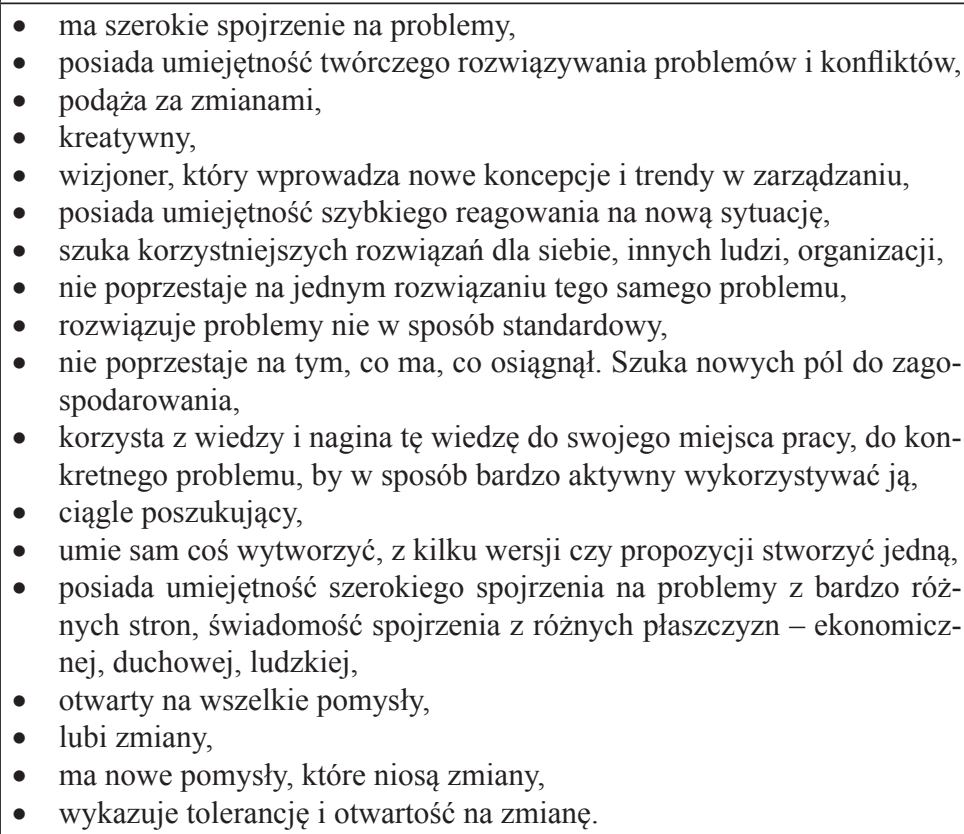 \\
\hline $\begin{array}{l}\text { Innowacyjne } \\
\text { umiejętności } \\
\text { zarządcze }\end{array}$ & $\begin{array}{l}\text { - } \quad \text { posiada umiejętność samodzielnego konstruowania i udoskonalania na- } \\
\text { rzędzi zarządczych, } \\
\text { - } \quad \text { skutecznie realizuje misje i strategie, } \\
\text { - } \quad \text { dprowadza nowy sposób zarządzania, } \\
\text { - cały czas ulepsza i zmienia czynności, procedury, }\end{array}$ \\
\hline $\begin{array}{l}\text { Cechy „dobrego } \\
\text { menedżera” }\end{array}$ & $\begin{array}{l}\text { - wysoka motywacja, } \\
\text { - umiejętność szybkiego reagowania na nową sytuację, } \\
\text { - } \text { umiejętność podejmowania trudnych decyzji, } \\
\text { - dobrze przygotowana osianganie celów, } \\
\text { - bierze odpowiedzialność za swoje decyzje, }\end{array}$ \\
\hline
\end{tabular}




\begin{tabular}{|l|l|}
\hline $\begin{array}{l}\text { Cechy „dobrego } \\
\text { menedżera” }\end{array}$ & $\bullet \begin{array}{l}\text { szybko podejmuje decyzje, szybko reaguje, } \\
\text { wie, czym się zajmuje jego dział, jego podwładni po to, aby odpowied- } \\
\text { nio przydzielić pracę, }\end{array}$ \\
$\qquad \begin{array}{l}\text { kultura osobista, } \\
\text { rozwinięte cechy planingowe, strategiczne. }\end{array}$ \\
\hline
\end{tabular}

Źródło: badania własne (Nawrat, 2009).

\subsubsection{Edukacja do twórczości i innowacji}

W ostatniej fazie wywiadu poprosiłam badanych, by opowiedzieli: w jaki sposób edukacja ukształtowała ich postawy innowacyjne?

Według badanych na kształtowanie postaw innowacyjnych wpłynęło i wpływa wiele czynników, które wzajemnie się przeplatają i łączą. Kluczowe, zdaniem badanych, są uwarunkowania podmiotowe (predyspozycje, cechy, zdolności, temperament), na co wskazywali we wcześniejszych wypowiedziach. Drugim, równie ważnym czynnikiem jest wpływ środowiska zawodowego - który uznali za niezwykle ważny. Te dwa czynniki muszą się jednak uzupełniać. Nawet wybitny menedżer czy pracownik może nie wykorzystywać swoich zdolności w niesprzyjających warunkach. Ta perspektywa przedstawiona przez badanych zgodna jest ze społeczno-osobowościowym podejściem do kształtowania postawy twórczej. Pozostałe uwarunkowania sprzyjające ich rozwojowi twórczemu i postawom innowacyjnym to czynniki: rodzinne, edukacyjne (edukacja formalna), środowiskowe (społeczne), zawodowe (organizacyjne). Wszystkie obszary zdaniem badanych odgrywają istotną rolę. Duże znaczenie miała edukacja nieformalna i pozaformalna, która, zdaniem wielu badanych, stanowiła podłoże głównie podmiotowe, wynikała bowiem z już ukształtowanej postawy przejawiającej się chęcią, ciekawością, otwartością, refleksyjnością, umiejętnością łączenia różnych elementów. Stosunkowo najmniej uwagi poświęcili badani opisywaniu uwarunkowań środowiskowych (społecznych, ale nie zawodowych), w związku z tym pomijam ten obszar w analizie.

\section{Uwarunkowania rodzinne}

Pewien wpływ na rozwój postaw innowacyjnych u większości badanych osób miała rodzina, zapewniając im we wczesnym okresie rozwoju (dzieciństwo, szkoła podstawowa) odpowiednią stymulację przy jednoczesnym wsparciu i dawaniu odpowiedniej przestrzeni niezależności i samodzielności. Wpływ rodziny objawiał się:

- pokazywaniem różnych możliwości,

- rozwijaniem ciekawości poznawczej,

- stymulowaniem do odwagi w samodzielnym podejmowaniu decyzji,

- rozwijaniem ambicji i motywacji do uczenia się. 
Charakterystyczne dla wypowiedzi badanych jest doświadczenie poczucia wolności i samodzielności, czyli pewnego obszaru wolności doświadczonego w dzieciństwie. Ten obszar przez kilkoro badanych wskazywany był wcześniej jako ważne doświadczenie edukacyjne. Ten większy lub mniejszy obszar wolności pozwolił badanym podjąć pierwszą odpowiedzialność za siebie, co zaprocentowało zwiększeniem samodzielności i poczucia niezależności, kształtowaniem własnej autonomii. Przestrzeń samodzielności pozwoliła badanym lepiej poznać siebie, odkryć słabe i mocne strony.

\section{Uwarunkowania podmiotowe}

Niektórzy badani opowiadali o posiadanych już w dzieciństwie wewnętrznych predyspozycjach, które przyczyniły się do późniejszego wyboru zawodu menedżera, a jednocześnie do kształtowania postawy innowacyjnej. Wymienili następujące dyspozycje:

- chęć liderowania,

- zdolności przywódcze,

- charyzma,

- postawa poszukującą,

- wczesna samodzielność,

- potrzeba niezależności i wolności osobistej,

- silna wewnętrzna motywacja do uczenia się i odniesienia sukcesu,

- wysokie aspiracje,

- chęć wybicia się,

- umiejętność stawiania sobie celów,

- wytrwałość w dążeniu do celu,

- wysoka tolerancja na zamiany,

- podejmowanie wyzwań,

- odporność na porażki czy raczej korzystanie z nich (uczenie się na błędach).

Oto wybrany przykład wypowiedzi: Już jako dziecko miałem $w$ swojej podświadomości, że to bardzo fajnie jest jak inni cię stuchają. I uświadomiłem sobie, że będę dobrym menadżerem (Bernard K.).

Powyżej wymienione dyspozycje umożliwiły badanym w okresie szkolnym uczenie się nowych umiejętności związanych ze społecznym funkcjonowaniem i radzeniem sobie w różnych sytuacjach. Większość badanych podjęła pierwsze samodzielne decyzje edukacyjne, a nawet życiowe w wieku od 12 do 15 lat (wybór zawodu, szkoły średniej, decyzja o nauce w innym mieście). Jest to wynik połączenia czynnika podmiotowego ze sprzyjającymi uwarunkowaniami rodzinnymi. Badani wcześnie także wykazywali się zaradnością, przebojowością, odwagą (szkoła podstawowa, średnia). Oto przykład: Jako dziecko mając 15 lat byłem sam zagranica na handlu. W wieku 12 lat jeździłem autostopem wokół Polski (Dawid O.).

Rozwój jednych dyspozycji stymulował rozwój innych i nabywanie nowych umiejętności. Wielość i różnorodność doświadczeń multiplikowała się, powodu- 
jąc coraz większą paletę możliwości: w zakresie działania, podejmowania decyzji, rozwiązywania problemów.

Cechy, które pomogły w kształtowaniu postawy innowacyjnej w opinii pani Marioli W. to: przebojowość, tatwość nawiazywania kontaktów, pęd do wiedzy, szukanie wyzwań, nowych możliwości. Wrażliwość, egzaltacja, nie mam pokerowej twarzy. Plakatam nawet przy szefie. Uważam to za dobre, ale w życiu zawodowym mi to utrudnia pewne sprawy.

Siedmioro spośród badanych sprawowało różne funkcje społeczne w toku edukacji szkolnej (gospodarz klasy, grupowy, inne). Te funkcje społeczne rozwijały, zdaniem badanych, umiejętności związane z zarządzaniem ludźmi, budowaniem relacji, współpracą i współdziałaniem, oto przykład: Zawsze lubiłem być organizatorem. Lepiej się czulem w funkcji organizatora niż osoby organizowanej. Uważatem, że jeżeli w wielu sytuacjach ja się za coś wezmę to będę miat nad tym kontrole i zostanie to wykonane (Marek N.).

Ponadto większość badanych realizowała równolegle z nauką szkolną swoje zainteresowania pozaszkolne (sport, gra w zespole muzycznym, harcerstwo, inne).

\section{Uwarunkowania edukacyjne (edukacja formalna)}

Zastanawiająca jest stosunkowo mała rola kształcenia formalnego w kształtowaniu postaw innowacyjnych badanych, według ich opinii. W ocenie menedżerów edukacja odegrała bardzo znaczącą rolę w ich życiu i karierze zawodowej - umożliwiła zdobycie wiedzy i kwalifikacji, rozwinęła myślenie, pamięć, umiejętności analityczne, ambicje i chęci do nauki, stosunkowo małą jednak w kształtowaniu postaw innowacyjnych. Badani wskazali niewiele znaczących wydarzeń szkolnych i stosunkowo niewiele autorytetów w postaci nauczycieli stymulujących twórczość i innowacyjność.

W obszarze edukacji formalnej najwięcej doświadczeń przyczyniających się do rozwoju postaw innowacyjnych wskazali badani z wyższym wykształceniem humanistycznym. Ich zdaniem studia te otworzyły ich na drugiego człowieka, na różnorodność (zwłaszcza etnologia, antropologia kulturowa), dały podstawowe narzędzia i umiejętności istotne $\mathrm{w}$ pracy menedżera, takie jak: narzędzia skutecznej komunikacji, umiejętność rozwiązywania konfliktów, negocjacje, wiedza o człowieku i jego zachowaniach (pedagogika, nauki o wychowaniu Dawid O.). Przykładowa wypowiedź: ja skończytem etnologię, antropologię kulturowa, to się wiązało $z$ wyjazdami, z wywiadami z nowym ludźmi, tutaj zdobytem umiejętności w nawiazywaniu kontaktów, zawsze byłem osoba otwarta, ale przy odbywaniu praktyk, nabratem takiej umiejętności, wyjeżdżając na praktyki staraliśmy się, aby wybrać ciekawe miejsca daleko dostępne, przeprowadzałem mnóstwo wywiadów z ludźmi, to byly sprecyzowane bardzo tematy, odległe od tego o czym teraz rozmawiamy, ale bardzo się przy tym dużo nauczytem (Dariusz K.).

Edukacja szkolna jeszcze raz została uznana przez badanych jako ,trampolina" do dalszego rozwoju i kariery, ale nie jako źródło edukacyjnych doświadczeń, zwłaszcza tych kształtujących innowacyjność. 


\section{Uwarunkowania organizacyjne}

Charakterystyczny dla badanych (z wyjątkiem jednej osoby) jest wczesny start zawodowy: bezpośrednio po maturze, na pierwszych latach studiów lub nawet wcześniej (Dawid O.). Podjęcie pracy przyspieszyło dojrzewanie do dorosłości. Łączenie pracy i studiów spowodowało konieczność efektywniejszej organizacji czasu i łączenia różnych obowiązków, co w pewnym stopniu przygotowało badanych do pełnienia funkcji menedżerskich, które wymagają między innymi właśnie takich kompetencji, oraz rozwinęło cechy twórcze związane z łączeniem różnych obszarów.

Środowiskiem, które najsilniej przyczyniło się, w opinii badanych, do formowania ich postaw innowacyjnych jest praca zawodowa, a szczególnie pełniona funkcja menedżerska. Wszyscy badani podkreślają, że w pracy nauczyli się najwięcej z tego, co jest im obecnie potrzebne do właściwego jej realizowania, szczególnie w zakresie praktycznych umiejętności, a także w zakresie innowacyjności. Praca menedżera wymusza postawę innowacyjną, jak twierdzili niektórzy. Jeden z badanych zauważył, że obecnie nie można nie być innowacyjnym menedżerem, gdyż $\mathrm{w}$ ten zawód $\mathrm{w}$ dzisiejszych czasach innowacyjność musi być wpisana. Związek pomiędzy funkcjonowaniem $\mathrm{w}$ innowacyjnej firmie a kształtowaniem innowacyjnej postawy tak opisał pan Adrian L.: Ja się tego wcześniej nie nauczyłem, trzeba posiadać pewne cechy osobowościowe, które się ma albo się nie ma. Trzeba być człowiekiem świadomym, gdyż dopiero wówczas można rozwijać pewne cechy osobowościowe. Świadomość to jest możliwość zrozumienia pewnych mechanizmów, dotknięcie tego prawdziwego zrozumienia, a nie nauczenia się czegoś. W tej firmie można nauczyć się bycia innowacyjnym menadżerem, uczestniczac w kulturze tej firmie, pracując tutaj oraz uczestnicząc w różnego rodzaju szkoleniach.

Z tej wypowiedzi wynika, że kluczowe znaczenie w kształtowaniu postawy innowacyjnej ma sprzężenie dwóch kluczowych czynników: $z$ jednej strony organizacja, $z$ drugiej zaś posiadanie pewnych cech osobowościowych.

Pan Piotr Z. uważa, że czynnikiem kształtującym jego innowacyjność są codzienne zadania i sytuacje firmowe: Ja się stykam z problemami natury prawnej, jak dojdzie do jakiegoś konfliktu to ja się muszę z tym zmierzyć, razem z radca prawnym, musze podjać decyzję czy to rozwiazanie jest dobre. Firma jest takim miejscem, gdzie mogę korzystać, eksperymentować. To ksztaltuje moja postawę innowacyjna, a nie sucha wiedza. Praca to taka forma edukacji, możliwość ćwiczenia. Nie ma jej się zawsze. Można ja mieć, gdy się ma odpowiednia postawę (Piotr Z.).

Kilkoro innych badanych ma podobne stanowisko. Pan Marek N. twierdzi, że praca menedżera niesie ze sobą każdego dnia cały szereg „ćwiczeń” i „treningów” twórczości i innowacyjności Oto przykładowe sytuacje „treningowe” wybrane z wypowiedzi badanych:

- podciągnięcie planu,

- odnalezienie czegoś, wykonanie sprawy trudnej, która była do wykonania, 
- rozwiązanie konfliktu,

- negocjacje z klientem,

- przygotowanie planu strategicznego,

- projekt nowego kierunku działań,

- podział odpowiedzialności,

- podążanie za tym, co się dzieje,

- motywowanie podwładnych,

- decyzje i wybory,

- zdobycie informacji,

- uzyskanie wzrostu sprzedaży.

Zdaniem badanych to organizacja kształci innowacyjnego menedżera poprzez stwarzanie odpowiednich warunków, klimat pracy sprzyjający innowacyjnym postawom.

Badani zdecydowanie wzbogaciliby proces edukacji do innowacji o następujące elementy:

- planowanie ścieżek rozwoju,

- umiejętności interpersonalne: negocjacje, kontakt z ludźmi, zauważanie drugiego człowieka i jego potrzeb, współpraca i komunikacja na wyższym poziomie, praca zespołowa, rozmowa i słuchanie, dzielenie się odpowiedzialnością,

- umiejętność rozwijania wewnętrznej motywacji, określania priorytetów,

- budowanie i wzmacnianie siebie,

- kształtowanie samodzielności i odpowiedzialności,

- umiejętność podążania za tym, co się dzieje,

- otwartość,

- umiejętność szerokiego spojrzenia na problemy z różnych stron i płaszczyzn (ekonomicznej, duchowej, ludzkiej),

- umiejętność dostosowania narzędzi pracy i struktury firmy do potrzeb,

- umiejętność budowania wizji i drogi dojścia do celu,

- korzystanie z możliwości, zasobów i wiedzy innych ludzi,

- rozwój duchowy,

- otwieranie się na inne kultury i doświadczenia innych,

- podróże,

- zmiany klimatu i otoczenia.

Zdaniem badanych, aby formować postawy innowacyjne w procesie kształcenia formalnego, należałoby poszerzyć programy i treści kształcenia, a także podejście do wychowanka i skierować je w stronę raczej kształcenia postaw i cech osobowych niż nabywania wiedzy i ćwiczenia umiejętności intelektualnych. Postawa innowacyjna jest związana, zdaniem badanych, z otwieraniem się na „nowe”, na odmienność drugiego człowieka, z poszukiwaniem własnej tożsamości i autonomii, podejściem niestandardowym, przekraczaniem granic, elastycznością. Edukacja formalna w większości przypadków nie zapewniła możliwości wykształcenia tych kluczowych dla innowacyjności cech i umie- 
jętności. Wyjątek stanowią dwie osoby, które wskazały na proinnowacyjne oddziaływanie studiów wyższych, ale jak już wspomniałam, byli to absolwenci kierunków humanistycznych.

\section{Podsumowanie}

Biografie edukacyjne menedżerów ukazują indywidualne, niepowtarzalne narracje poszczególnych osób, a jednocześnie wskazują na wspólne rozumienia i oczekiwania kierowane wobec edukacji. Zbieżne dla przedstawionych narracji jest postrzeganie edukacji w szerokiej perspektywie, jako procesu całożyciowego i związanego ze wszystkimi obszarami aktywności człowieka. Analiza narracji skłania do refleksji - co jest, a co powinno być przedmiotem edukacji szkolnej? Czy edukacja ta sprzyja kształtowaniu kompetencji innowacyjnych, a jeśli nie - dlaczego? Innowacyjność - definiowana przez menedżerów bardzo różnorodnie - przez wszystkich uznana jest jako ważny lub nawet kluczowy czynnik zarządzania i radzenia sobie $\mathrm{z}$ wyzwaniami współczesnego świata. Znamienne jest, że kompetencje innowacyjne badanych menedżerów kształtowały się w wyniku różnorodnych czynników - wydawać by się mogło pozaedukacyjnych - w powiązaniu z określonymi cechami osobowości. Badani wskazywali między innymi na: uwarunkowania rodzinne, możliwość rozwijania zainteresowań i pasji, motywowanie do rozwoju i osiągania celów, działalność społeczną i relacje rówieśnicze, wczesną samodzielność i podjęcie pracy, duże pole wolności i odpowiedzialność za nie, rolę środowiska pracy i zadań zawodowych wyzwalających innowacyjność, tolerancję na różnorodność kształtowaną na przykład podczas podróży czy poznawania innych kultur.

Badania pokazały, jak ważne miejsce w procesie całożyciowego uczenia się odgrywa praca zawodowa oraz środowisko pracy, które może stymulować innowacyjność lub ją hamować. Style kierowania realizowane przez menedżerów, relacje pomiędzy członkami organizacji oraz rodzaje zadań i sposoby rozwiązywania problemów kształtują klimat do uczenia się i innowacji. Środowisko pracy może więc stanowić ważny ośrodek uczenia się i kształtowania kompetencji innowacyjnych.

\section{Literatura}

Amabile T. M., 1983, The social psychology of creativity, Springer-Verlag, New York. Csikszalmychalyi M., 1996, Przepływ. Jak poprawić jakość życia, Studio Emka, Warszawa.

Czapski J., „Koło”- Shalita kwestionariusz stylu spostrzegania, [w:] L. Wołoszynowa (red.), Materiaty do nauczania psychologii, seria III, t. IV, PWN, Warszawa.

Czarnecki K., Karaś S., 1996, Profesjologia w zarysie: rozwój zawodowy człowieka, Wydawnictwo ITE, Radom. 
Dobrołowicz W., Bednarek J., Stasiak M. K., Gralewski J., 2007, Kreatywność kluczem do sukcesu w mediach i przedsiębiorstwach, Wydawnictwo Wszechnica Polska Szkoła Wyższa Towarzystwa Wiedzy Powszechnej, Warszawa 2008.

Dubas E., 2005, Dorostość edukacyjnym paradygmacie, czyli dorostość jako edukacyjny okres życia człowieka, [w:] M. Podgórski (red.), Człowiek na edukacyjnej fali. Współczesne konteksty edukacji dorostych, Wydawnictwo Impuls, Kraków.

Dziennik Urzędowy Unii Europejskiej 2006/962/WE

Filipowicz G., 2004, Zarządzanie kompetencjami zawodowymi, Polskie Wydawnictwo Ekonomiczne, Warszawa.

Giza A., 1991, Życie jako opowieść, Zakład Narodowy im. Ossolińskich, Wydawnictwo PAN, Wrocław, Warszawa, Kraków.

Jankowski D., Przyszczypkowski K., Skrzypczak J., 2007, Podstawy edukacji dorostych, Wydawnictwo Naukowe UAM, Poznań.

Kargul J., 2001, Obszary pozaformalnej i nieformalnej edukacji dorostych, Wrocław.

Karwowski M., 2009, Klimat dla kreatywności. Koncepcje, metody, badania, Wydawnictwo Difin, Warszawa.

Karwowski M., 2009, Zgłębianie kreatywności. Studia nad pomiarem poziomu stylu twórczości, Wydawnictwo Akademii Pedagogiki Specjalnej, Warszawa.

Katz D., Kahn R., 1997, Spoleczna psychologia organizacji, PWN, Warszawa.

Kozielecki J., 1987, Koncepcja transgresyjna człowieka, PWN, Warszawa.

Kozielecki J., 1987, Człowiek oświecony czy innowacyjny, „Kwartalnik Pedagogiczny”, UW Wydział Pedagogiczny, nr 1, s. $3-16$.

Król H., Ludwiczyński A., 2006, Zarządzanie zasobami ludzkimi. Tworzenie kapitału ludzkiego w organizacji, Wydawnictwo Naukowe PWN, Warszawa.

Malewski M., 2002, Edukacja dorostych w pojęciowym zgietku. Próba rekonstrukcji zmieniajacej się racjonalności andragogiki, [w:] E. Malewska, B. Śliwerski, Pedagogika i edukacja wobec nowych wspólnot i różnic w jednoczącej się Europie. Materiaty z IV Ogólnopolskiego Zjazdu Pedagogicznego, Kraków.

Mesjasz J., 2004, Psychologiczne koszty sukcesu a zarzadzanie własna kariera, [w:] M. Romanowska, M. Trocki (red.), Podejście procesowe w zarządzaniu, Wydawnictwo SGH, Warszawa.

Mesjasz J., 2006, Kultura i klimat w organizacji transgresyjnej, [w:] M. Romanowska, P. Wachowiak (red. nauk.), Koncepcje i narzędzia zarządzania strategicznego, SGH, Warszawa, s. 635-646.

Mesjasz J., Nawrat D., 2007, Doskonalenie kompetencji menedżerskich a psychologiczne koszty pracy, [w:] W. M. Grudzewski (red.), Rozwój i funkcjonowanie przedsiębiorstw w warunkach globalnej gospodarki światowej, Wydawnictwo Agencja Artystyczna PARA, Katowice.

Mesjasz J., Witkowski S. A., 2003, Bilansowanie psychologicznych kosztów pracy jako wyznacznik efektywności zawodowej menedżerów, [w:] J. Stankiewicz (red.), Wspótczesne problemy i koncepcje zarządzania, Oficyna Wydawnicza Uniwersytetu Zielonogórskiego, Zielona Góra, s. $167-174$.

Morawski M., 2004, Kompetencje menedżerów w procesie zarządzania wiedza, [w:] Sukces w zarzadzaniu kadrami, Wydawnictwo Akademii Ekonomicznej we Wrocławiu, Wrocław.

Mroziewski M., 2008, Kapitat intelektualny współczesnego przedsiębiorstwa, Difin, Warszawa.

Nawrat D., 2007, Podmiotowy rozwój organizacji, [w:] W. Dobrołowicz, J. Bednarek, M. K. Stasiak, J. Gralewski, Kreatywność kluczem do sukcesu w mediach i przedsiębiorstwach, Wydawnictwo Wszechnica Polska Szkoła Wyższa Towarzystwa Wiedzy Powszechnej, Warszawa 2008.

Nawrat D., 2008, Kompetencje menedżerskie w zarządzaniu innowacyjnym, [w:] Wspótczesne koncepcje zarzadzania, Wydawnictwo WSHE, Łódź.

Nęcka E., 2001, Psychologia twórczości, Gdańskie Wydawnictwo Psychologiczne, Gdańsk.

Nittel D., 1991, Report: Biographieforschuhg, Reinheim. 
Nowacki T. W., 2004, Leksykon pedagogiki pracy, ITeE, Radom.

Penc J., 1999, Innowacje i zmiany w firmie. Transformacja i sterowanie rozwojem przedsiębiorstwa, Agencja Wydawnicza Placet, Warszawa.

Pietrasiński Z., 1971, Ogólne i psychologiczne zagadnienia innowacji, PWN, Warszawa.

Pilch T., Bauman T., 1998, Zasady badań pedagogicznych, Wydawnictwo Akademickie „Żak”, Warszawa.

Podolska-Filipowicz E., 1996, Podstawy zawodoznawstwa, orientacji i poradnictwa zawodowego, Bydgoszcz.

Pomykalski A., 2001, Zarządzanie innowacjami, Wydawnictwo Naukowe PWN, Warszawa-Łódź.

Popek S., 2000, Kwestionariusz Twórczego Zachowania KANH, wyd. 2, Wydawnictwo UMC-S, Lublin.

Popek S., 2001, Człowiek jako jednostka twórcza, Wydawnictwo UMCS, Lublin.

Potocki A., 2005, Zachowania organizacyjne, Difin, Warszawa.

Proctor T., 2001, Twórcze zarządzanie, Wydawnictwo Felberg SJA, Warszawa.

Rakowska A., Sitko-Lutek A., 2000, Doskonalenie kompetencji menedżerskich, Wydawnictwo Naukowe PAN, Warszawa.

Ratajczak Z., 1980, Człowiek w sytuacji innowacyjnej, PWN, Warszawa.

Rostkowski T., Sienkiewicz Ł., 2003, Zintegrowany system zarządzania kompetencjami, [w:] M. Juchnowicz (red.), Narzędzia i praktyka zarządzania zasobami ludzkimi, Poltex, Warszawa.

Sajkiewicz A., 2002, Jakość zasobów pracy, kultura, kompetencje, konkurencyjność, Poltext, Warszawa.

Schütze F., Bigraphieforschung und narratives Interview, „Betrifft Erziehung” 1982a, cyt. za: I. K. Helling, Metoda badań biograficznych, [w:] J. Włodarek, M. Ziółkowski (red.), 1990, Metoda biograficzna w socjologii, PWN, Warszawa-Poznań.

Sitko-Lutek A., 2004, Kulturowe uwarunkowania doskonalenia menedżerów, Wydawnictwo UMC-S, Lublin.

Sloane P., 2005, Twórcze myślenie w zarządzaniu, Gdańskie Wydawnictwo Psychologiczne, Gdańsk. Sołowiej J., 1997, Psychologia twórczości, Wydawnictwo Uniwersytetu Gdańskiego, Gdańsk.

Stasiakiewicz M., 1999, Twórczość i interakcja, Wydawnictwo Naukowe UAM, Poznań.

Steiner E., Weber R., 1993, Ekonomika i organizacja produkcji, nr 3.

Sułkowski Ł., 2002, Kulturowa zmienność organizacji, PWE, Warszawa.

Szmidt K., 2007, Dydaktyka twórczości, Wydawnictwo WSHE, Łódź.

Szopiński J., 2004, Kreatywność menedżerów a ich funkcjonowanie rodzinne, zawodowe i osobowościowe, Wydawnictwo UJ, Kraków.

West M., 2000, Rozwijanie kreatywności w organizacji, Wydawnictwo Naukowe PWN, Warszawa.

Włodarek J., Ziółkowski M. (red.), 1990, Metoda biograficzna w socjologii, PWN, Warszawa-Poznań.

Wołk Z., 2005, Rozwój zawodowy na tle życia. Życie człowieka jako proces rozwojowy, „Problemy Profesjologii”, nr 1, s. 41. 